\title{
A fast, efficient and high-throughput procedure involving laser microdissection and RT droplet digital PCR for tissue- specific expression profiling of rice roots
}

Thibault Mounier ${ }^{1 \dagger}$, Sergi Navarro-Sanz ${ }^{1 \dagger}$, Charlotte Bureau ${ }^{1 \dagger}$, Lefeuvre Antoine ${ }^{2}$, Fabrice Varoquaux ${ }^{1}$, Franz Durandet ${ }^{2}$ and Christophe Périn ${ }^{1 *}$ (i)

\begin{abstract}
Background: In rice, the cortex and outer tissues play a key role in submergence tolerance. The cortex differentiates into aerenchyma, which are air-containing cavities that allow the flow of oxygen from shoots to roots, whereas exodermis suberification and sclerenchyma lignification limit oxygen loss from the mature parts of roots by forming a barrier to root oxygen loss (ROL). The genes and their networks involved in the cellular identity and differentiation of these tissues remain poorly understood. Identification and characterization of key regulators of aerenchyma and ROL barrier formation require determination of the specific expression profiles of these tissues.

Results: We optimized an approach combining laser microdissection (LM) and droplet digital RT-PCR (ddRT-PCR) for high-throughput identification of tissue-specific expression profiles. The developed protocol enables rapid (within 3 days) extraction of high-quality RNA from root tissues with a low contamination rate. We also demonstrated the possibility of extracting RNAs from paraffin blocks stored at $4^{\circ} \mathrm{C}$ without any loss of quality. We included a detailed troubleshooting guide that should allow future users to adapt the proposed protocol to other tissues and/or species. We demonstrated that our protocol, which combines LM with ddRT-PCR, can be used as a complementary tool to in situ hybridization for tissue-specific characterization of gene expression even with a low RNA concentration input. We illustrated the efficiency of the proposed approach by validating three of four potential tissue-specific candidate genes detailed in the RiceXpro database.
\end{abstract}

Conclusion: The detailed protocol and the critical steps required to optimize its use for other species will democratize tissue-specific transcriptome approaches combining LM with ddRT-PCR for analyses of plants.

Keywords: Rice, Root meristem, Laser microdissection (LM), Cortex, ddRT-PCR, Droplet digital PCR

\footnotetext{
* Correspondence: perin@cirad.fr

†Thibault Mounier, Sergi Navarro Sanz and Charlotte Bureau contributed equally to this work.

${ }^{1}$ CIRAD, UMR-AGAP, Université de Montpellier, Avenue Agropolis, F-34398 Montpellier Cedex 5, France

Full list of author information is available at the end of the article
}

(c) The Author(s). 2020 Open Access This article is licensed under a Creative Commons Attribution 4.0 International License, which permits use, sharing, adaptation, distribution and reproduction in any medium or format, as long as you give appropriate credit to the original author(s) and the source, provide a link to the Creative Commons licence, and indicate if changes were made. The images or other third party material in this article are included in the article's Creative Commons licence, unless indicated otherwise in a credit line to the material. If material is not included in the article's Creative Commons licence and your intended use is not permitted by statutory regulation or exceeds the permitted use, you will need to obtain permission directly from the copyright holder. To view a copy of this licence, visit http://creativecommons.org/licenses/by/4.0/ The Creative Commons Public Domain Dedication waiver (http://creativecommons.org/publicdomain/zero/1.0/) applies to the data made available in this article, unless otherwise stated in a credit line to the data. 


\section{Background}

Aerenchyma formation is tightly developmentally controlled in rice roots. Moreover, aerenchyma are fragile tissues embedded between vascular and outer cell layers; thus, identifying gene networks involved in aerenchyma is challenging and requires the development of specific RNA extraction procedures for downstream applications such as RNAseq. Three main technologies have been developed for the isolation of RNA from specific tissues, and these can be grouped into two groups: technology involving laser microdissection (LM) [1] and FACS [2] and INTACT [3, 4] technologies.

The FACS and INTACT technologies use transgenic lines and specific tissue promoters that express fluorophores or a nuclei-tagged protein [2-4], respectively. Seedlings are then digested to produce protoplasts for FACS and nuclei for INTACT. These protoplasts and nuclei are separated into GFP-labeled and unlabeled populations, using a cell sorter (FACS) or an affinity column (INTACT). RNAseq or microarray is then used to obtain an expression profile of the labeled cell populations. These technologies have mainly been used for the analysis of $A$. thaliana (e.g., [2] and to a lesser extent for the analysis of rice (e.g., $[5,6]$. For A thaliana, the development of FACS technology has made it possible to produce a map of the expression profiles of most root cell types [2] and to analyze tissue-specific responses to salt stress [7].

The INTACT and FACS approaches require transgenic plants and tissue or cell-specific promoters. Moreover, for FACS, the protoplast isolation step generates biases and often cross-contamination that are sometimes difficult to control, and thus, a set of stress control experiments are needed [7]. In contrast, INTACT requires only frozen tissues for the isolation of nuclei through affinity purification [5]. These technologies cannot be used to isolate few cells from a specific tissue unless a specific promoter is available, require large quantities of biological material proportional to the number of labeled cells and are well suited for large-scale transcriptomics experiments.

LM technology is complementary to FACS and INTA CT technologies. It involves the laser cutting of paraffinembedded or frozen tissue sections for the extraction of specific RNAs that can be used to determine expression profiles using DNA chips or RNAseq (e.g., $[8,9]$. This technology has been used for the analysis of a larger number of species because it does not require tissuespecific promoters or the generation of transgenic plants. Theoretically, it can be used for gene-specific expression profiling in small-scale experiments. In particular, this technology has been used to isolate root tissues from rice [1, 10]; however, the technology requires optimization of many parameters, such as those associated with fixation, dehydration, paraffin embedding, and laser steps [9], and has therefore been mastered only by a few laboratories.

In our first experiments using an LM-based approach to isolate RNA from the cortex of rice roots, we used available published protocols $[8,9,11]$ but found that isolating good-quality RNA (RIN $>7$ ) while maintaining an intact tissue structure was difficult. This finding encouraged us to re-perform each step to determine the key parameters and to rationally optimize each step by attempting to identify the main sources of variation in the quality and quantity of RNA and the tissue structure.

RNAs extracted through LM can be used to perform transcriptomic analyses by RNAseq or microarray or directly to determine the tissue-specific expression profiles of candidate genes. These expression analyses are most often performed by qPCR or RT-PCR but have several difficulties. The quantities of extracted RNA are extremely small, with results in the need for a large amount of tissues and/or the use of amplification systems that potentially introduce bias. qPCR is sensitive to potential contaminants and PCR inhibitors, and its reliability requires almost-perfect PCRs. Unfortunately, the most interesting samples are those containing small quantities of the targets, which can result in small or very small expression differences, and these samples are potentially contaminated by PCR contaminants present in paraffin samples [12].

Similar to qPCR, droplet digital PCR (ddPCR), which is a recently developed technology, uses Taq polymerase in PCRs to amplify the targets but has two important advantages compared with qPCR [13]. The PCRs are distributed in 20,000 independent droplets, and expression data are collected at the end of the PCR. These two differences allow direct quantification without a standard curve to obtain more accurate and repeatable results. The fluorescence measurements at the end of the reaction in each droplet (yes/no, hence the term digital PCR) enable expression quantification independent of the PCR efficiency [13]. RT-ddPCR can therefore also be used to measure the expression level of genes in samples containing extremely small quantities of the targets as well as PCR contaminants [12]. To the best of our knowledge, RT-ddPCR, despite its potential, has not yet been used to test gene expression in combination with LM.

We developed a simplified, high-throughput protocol involving the use of LM and ddPCR to extract highquality RNA, control intertissue contamination, and analyze gene expression. We identified key steps and simple solutions for any research group wishing to use this protocol for other tissues of other species. We also obtained evidence showing that this protocol can be applied to samples with a low level of intertissue contamination through the use of tissue-specific markers. We 
demonstrated the possibility of storing paraffin samples without any loss of quality for at least 6 months, which would enable sample collection from plant species in the field. Finally, we showed that ddRT-PCR can be used to evaluate the tissue specificity of candidate genes directly from RNA extracted by LM, indicating that the proposed protocol can be considered a powerful and complementary tool to in situ hybridization and in situ RTPCR. ddRT-PCR can also be used as quality control test before any downstream application such as RNAseq. Lastly, we illustrated the efficiency and novelty of our approach in determining tissue-specific expression using candidates extracted from the RiceXpro database $[14,15]$.

The complete protocol and the associated troubleshooting guide should make it possible to democratize approaches combining LM with ddRT-PCR for use in numerous applications associated with plant development.

\section{Results}

\section{Summary of the LM protocol}

The full protocol, including the critical steps (notes) and advice for researchers wishing to apply the protocol to other tissues or species, is detailed in Supplemental File 1 (see also Methods). Briefly, the first step constitutes germination of the rice seeds in an ARALAB (Supplemental Figure S1) using a hydroponics net floating system (Figure $\mathrm{S} 1 \mathrm{~A}$ ), the subsequent collection of $2-\mathrm{cm}$ root tips from 7-day-old seedlings and their overnight impregnation with fixative. Bundles of eight aligned roots are collected, and one root is stained with eosin (Figure S1B) to visualize the bundles in future paraffin blocks. In the second step, the root bundles are positioned in biopsy cassettes and trapped with biopsy foam (Figure S1C). After dehydration, the cassettes are immersed in a microwave water bath for embedding in paraffin. Finally, the bundles are positioned in liquid paraffin on a cold block (Figure S1D) and then soaked in the solidifying paraffin. In the third step, a microtome is used to cut the blocks approximately $300 \mu \mathrm{m}$ from the root cap by placing the bundle in the block using the eosin-labeled roots, and the cuts are placed on the blades for LM. Finally, the sections are dewaxed, and the tissues are laser cut at 40x or 63x magnification. The tubes are stored at $-80^{\circ} \mathrm{C}$ until extraction. The entire process, from sample collection to RNA determination, takes only 3 days to obtain high-quality tissue-specific RNAs for downstream RNAseq or RT-ddPCR experiments.

We started with the Takahashi protocol published in 2010. In our first experiments, we rapidly noted that the samples were histologically degraded, and that the RIN was below 3 (see Supplemental Figure S2 depicting the RIN evolution from Takahashi's protocol to the final improved protocol); in particular, the structure of the root cuts was not preserved. We therefore first sought to identify a protocol that preserves the structure of the root tissue.

\section{The use of biopsy foam for sample immobilization preserves root tissues}

We immobilized the root tips collected using biopsy foam when positioning the samples in the embedding cassettes (see Supplemental Figure S1C). Comparison of the sections obtained without foam (Fig. 1a) and those obtained with foam (Fig. 1b) showed that the use of biopsy foam likely prevents movement of the samples during the dehydration and embedding steps as the foam contacts the edges of the cassette or settles between samples to preserve the external tissues and the integrity of the internal tissues (Fig. 2).

\section{Reducing the duration of the paraffin embedding steps also preserves the integrity of root tissues}

The use of biopsy foam limited root tip degradation, but the external tissues were still damaged (data not shown). We therefore sought to reduce the embedding time and measure its effect based on the assumption that the heat contact time gradually degrades external tissues. Figure 3 shows the effect of the embedding time on external tissues. All the structures were preserved after $10 \mathrm{~min}$ of embedding (Fig. 3a), and the external tissues were partially (Fig. 3b) or completely collapsed (Fig. 3c) after 20 and $30 \mathrm{~min}$ of embedding, respectively.

\section{The embedding time affects the quantity but not the quality of extracted RNA}

All root tissues were cut with LM after 10, 20 and 35 min of paraffin embedding, and the quality (RIN) and quantity $\left(\mathrm{pg} / \mu \mathrm{m}^{2}\right)$ of the extracted RNA were assessed. First, $10 \mathrm{~min}$ of paraffin embedding allowed the extraction of very high-quality RNA (RIN between 8 and 9, Fig. 4a), and high-quality RNA was also obtained with 20 and 30 min of embedding (RIN of approximately 8 , not significantly different). Usually, paraffin inclusion time is negatively correlated with the quality of extracted RNA [11]. Our longest inclusion time, $30 \mathrm{~min}$, is short compared to most published protocols (see for instance [9] with $5 \mathrm{~h}$ embedding time) but this does not exclude negative correlation with longer inclusion times. Increasing the embedding time decreased the amount of extracted RNA per unit area; specifically, the amount decreased from $0.010 \mathrm{pg} / \mu^{2}$ with $10 \mathrm{~min}$ of embedding to $0.0038 \mathrm{pg} / \mu \mathrm{m}^{2}$ with $30 \mathrm{~min}$ of embedding $(p<0.01)$, resulting in a decrease of more than half (Fig. 4b). We therefore set the duration of the paraffin embedding step to $10 \mathrm{~min}$ in the following experiments. 

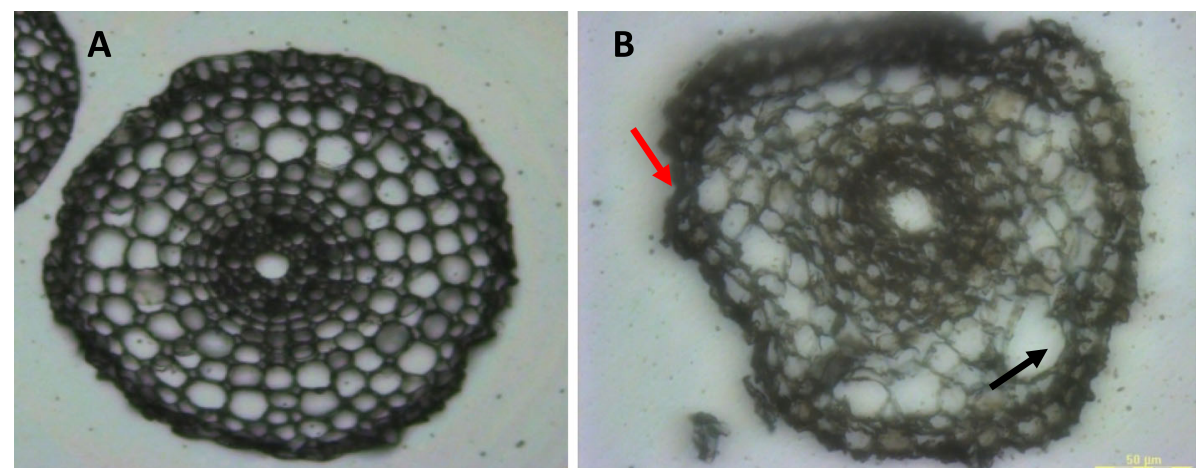

Fig. 1 Impact of the use of biopsy foam in the dehydration and embedding steps on root tissue integrity. a Root radial section obtained after the dehydration and embedding treatments using biopsy foam. $\mathbf{b}$ Same as (a) without the use of biopsy foam. The root is deformed and no longer circular, and the images show destruction of the most outer cellular layers, which were no longer distinguishable (red arrow), and bursting of more inner cells, such as in the cortex (black arrow). Bar $=50 \mu \mathrm{m}$

\section{RNA can be extracted without any loss of quality from paraffin blocks stored for longer than 6 months}

Our institute works with many tropical species, and there is often a delay from the time of sample collection in the field to their analysis. In addition, decoupling the paraffin embedding step from the LM cutting step to allow storage of the samples and making LM cuts only when this device, which is generally accessible through shared platforms, is available are desirable. We therefore tested whether the storage of paraffin blocks at $4{ }^{\circ} \mathrm{C}$ altered the quality and quantity of the extracted RNA. The qualities of the RNA samples extracted from paraffin blocks after 15 days, 40 days or 8 months of storage at $4{ }^{\circ} \mathrm{C}$ were equivalent to those obtained from 1-day blocks (Fig. 4c, RIN values of 8, 6.5, 7 and 7, respectively, not significantly different). The RNA amounts extracted 1, 15 and 40 days after embedding in paraffin were also very similar, with values of $0.01 \mathrm{pg} / \mu \mathrm{m}^{2}, 0.01 \mathrm{pg} / \mu^{2}$ and $0.014 \mathrm{pg} /$ $\mu \mathrm{m}^{2}$, respectively (Fig. $4 \mathrm{~d}$ ).
The quality and quantity of extracted RNA are correlated with the amount of tissue collected

We attempted to determine whether collecting a greater amount of tissue would increase the quality and quantity of the extracted RNA, which would allow identification of a minimum surface area for future LM experiments. We used RNA extracted from paraffin blocks stored for 1 day, 15 days and 30 days (Fig. 5). First, we observed a slight but nonsignificant increase in RNA quality with an increasing amount of tissue (Fig. 5a, c and e). Most of the extracted RNA had a RIN higher than 7 despite a few poor-quality extraction products. As expected, we also observed a positive correlation between the RNA quantity and tissue quantity (Fig. 5d, f) except for in the 1-day storage block (Fig. 5b), which was probably due to a stochastic effect of a single outlier (Fig. 5B). Overall, we achieved a RIN greater than 7 , reflecting a largely sufficient RNA quality for RNAseq or RTddPCR applications.
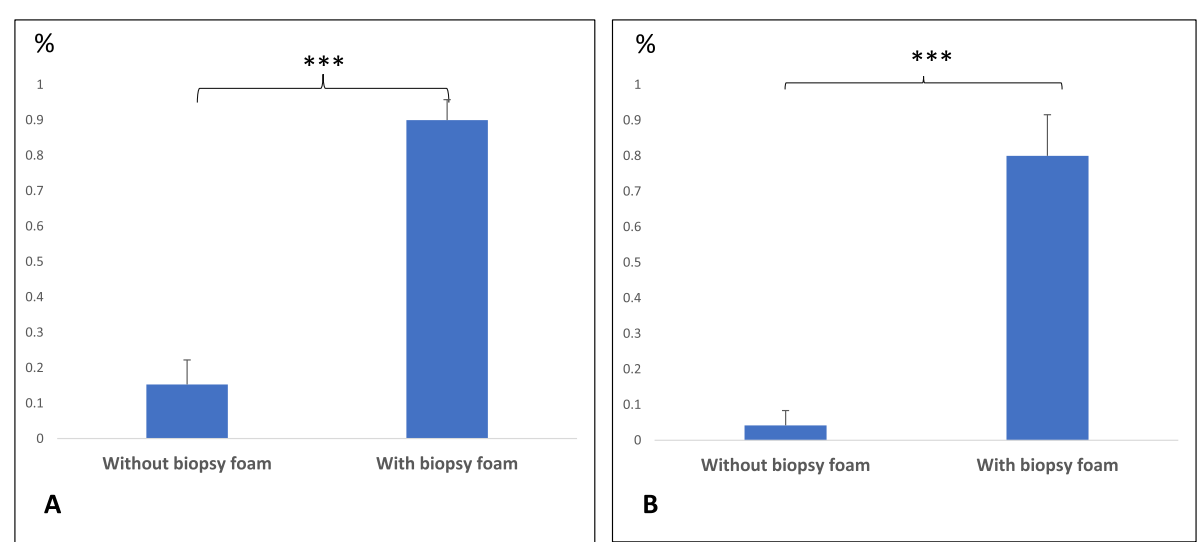

Fig. 2 Percentages of crushed and deformed tissues in root tissues with and without biopsy foam. a The percentage of crushed external tissue cross sections per total root sections without (left) or with biopsy foam (right). $\mathbf{b}$ The percentage of round-shaped cross sections per total root sections without (left) or with biopsy foam (right). Bilateral student t-test $\left({ }^{* * *}, p<0.001\right)$ 

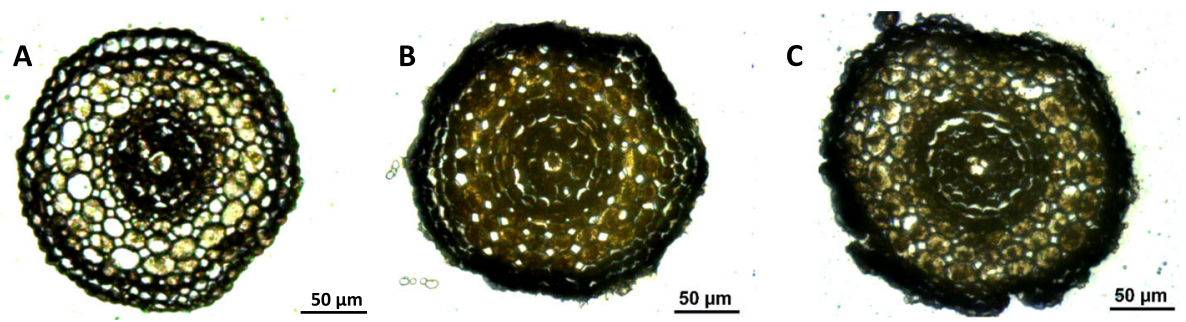

Fig. 3 Impact of the embedding time on root tissue integrity. Root cross section obtained after $10 \mathrm{~min} \mathbf{a}, 20 \mathrm{~min} \mathbf{b}$ and 30 min $\mathbf{c}$ of paraffin embedding. Root structure deformation became visible after $20 \mathrm{~min} \mathbf{b}$, and $30 \mathrm{~min} \mathbf{c}$ resulted in substantial deformation, as demonstrated by a loss of the structure of the external tissues and an inability to distinguish the different external tissues (epidermis, exodermis and sclerenchyma). In contrast, an embedding time in paraffin of $10 \mathrm{~min}$ (a) yielded tissues without any visible deformation

Our optimized LM protocol combined with ddPCR offers a complementary tool to in situ hybridization and/or RTPCR in situ experiments

We used the RT-PCR ddPCR kit from Bio-Rad (See Table 1 for probes and primers) to assay the feasibility of profiling genes from LM-derived samples with a low RNA quantity. This technology is highly sensitive and specific and can be applied to samples with degraded RNA and a very low RNA amount.

Two genes were first tested as constitutive controls for expression analysis by RT-ddPCR (Fig. 6): TFIIE, a class
IIE transcription factor that is assumed to be constitutively expressed in all transcriptionally active cells, and EXP', a gene with unknown function that was previously identified as a uniformly expressed gene based on a microarray expression dataset [20] (Table 1). Both genes generated only one or two positive droplets in the negative control. From $1 \mathrm{ng}$ of total root RNA, TFIIE (Fig. 6a) and EXP' (Fig. 6b) generated 2215 and 5814 positive droplets among 13,023 and 13,473 droplets, respectively, which indicates that these genes are expressed at sufficiently high levels to be used as standardization controls
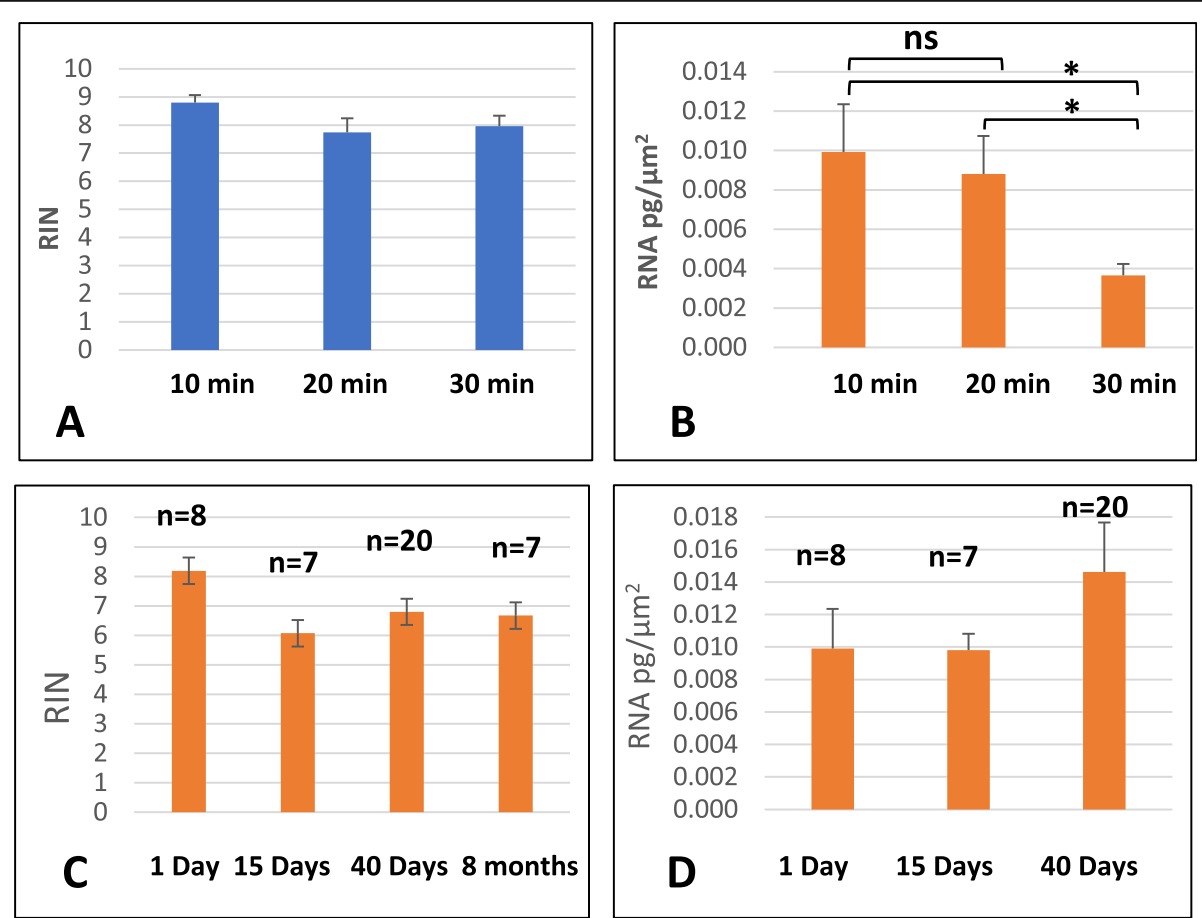

Fig. 4 Effects of the embedding time and paraffin block storage on the quality and quantity of extracted RNA from LM root cross sections. Effects of the paraffin embedding time on the quality of extracted RNA a) and the amount of extracted RNA (pg/ $\left.\left./ \mathrm{m}^{2}\right) \mathbf{b}\right)$. The data are shown as the means and standard errors calculated from six biological repeats. The effects of the storage time of paraffin blocks at $4^{\circ} \mathrm{C}$ on the quality of extracted RNA (RIN) $\mathbf{c}$ ) and the amount of extracted RNA $\left(\mathrm{pg} / \mu \mathrm{m}^{2}\right) \mathbf{d}$ ). Bilateral student t-test (*, $p<0.1$, ns = not significantly different) 


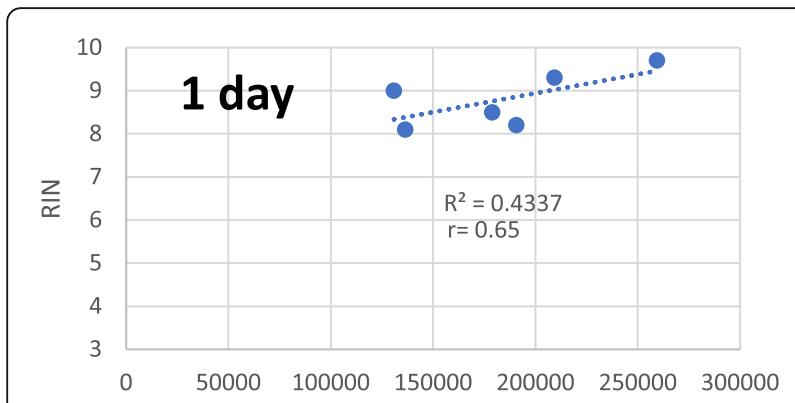

A surface
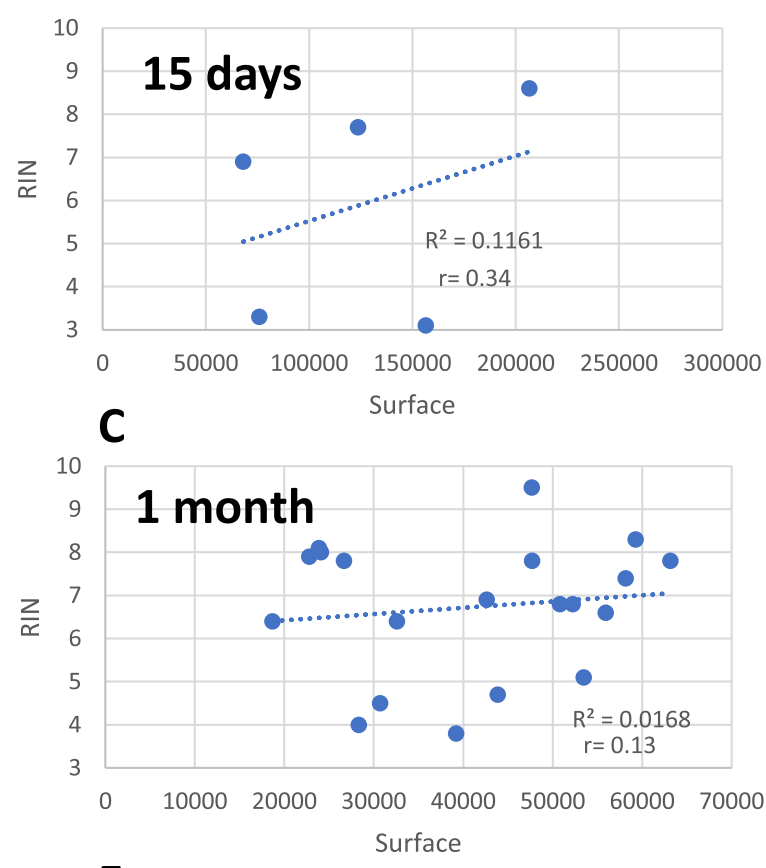

E
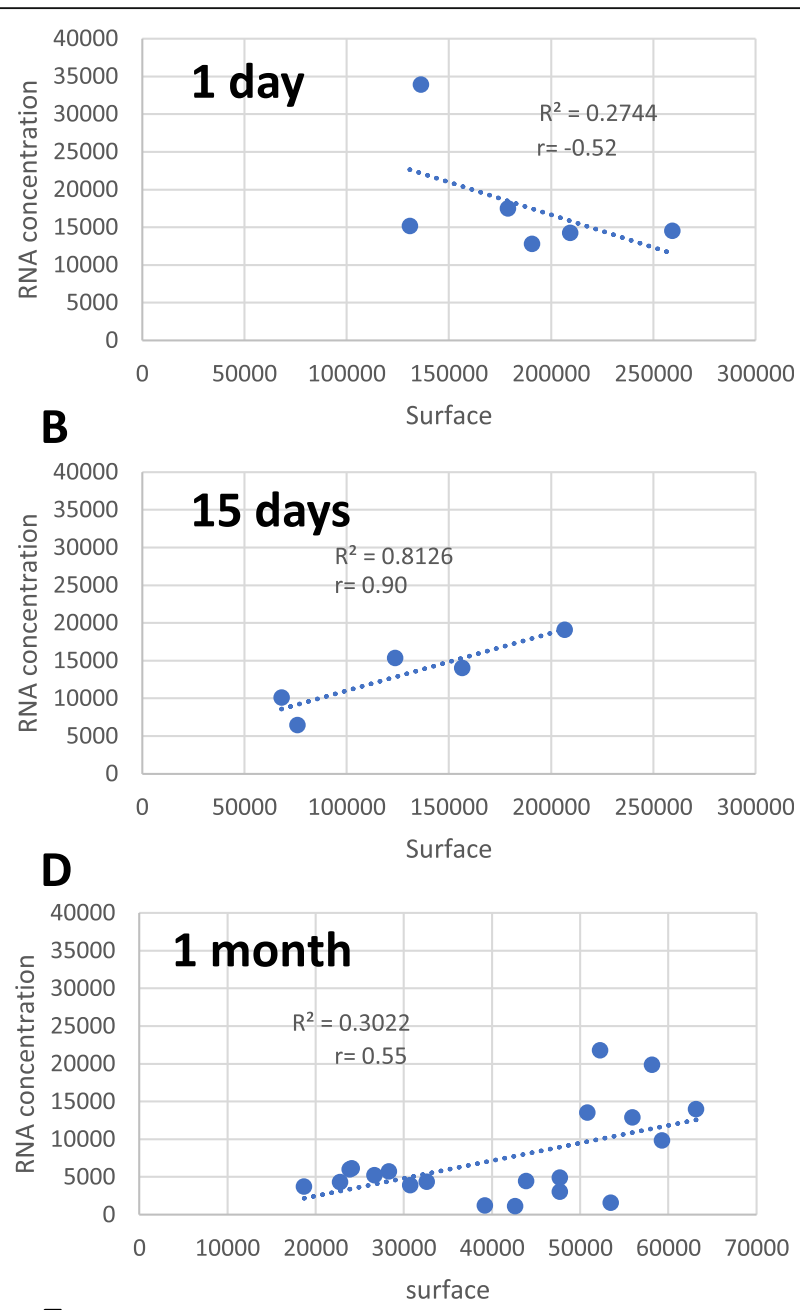

$\mathbf{F}$

Fig. $\mathbf{5}$ Correlations between the surface of microdissected tissue and the quantity and quality of extracted RNA $(n=6)$. $\mathbf{a}, \mathbf{c}, \mathbf{e}$ The quality of extracted RNA (RIN) as a function of the surface area of microdissected tissue $\left(\mu \mathrm{m}^{2}\right)$ after 1,15 and 30 days of paraffin block storage at $4{ }^{\circ} \mathbf{c} . \mathbf{b}, \mathbf{d}, \mathbf{f}$ The quantity of extracted RNA (pg) as a function of the surface area of microdissected tissue $\left(\mu \mathrm{m}^{2}\right)$ after 1,15 and 30 days of paraffin block storage at $4^{\circ} \mathrm{C}$

for small amounts of RNA, such as those obtained using LM. In addition, EXP' is expressed at a higher level compared with TFIIE (Fig. 6).

We successively microdissected three root tissues, stele+endodermis, cortex and outer cell layers (epidermis+exodermis+sclerenchyma) on approximately 30 roots using our LM protocol (Fig. 7). To validate our tissue-specific data, we used OsSHR1 as a specific tissue control (Fig. 8a). In situ hybridization experiments [21] have revealed that OsSHR1 is expressed specifically in the stele, and our results confirm that OsSHR1 is almost exclusively expressed in the stele and expressed at much lower levels, albeit still easily detectable by ddRT-PCR, in the cortex and outer cell layers (Fig. 8a), confirming the absence or a low level of tissue inter-contamination.

\section{Application of LM and ddRT-PCR for validation of tissue- specific candidate genes}

Our aim was to screen candidate expression profiles to identify tissue-specific genes using bibliography sources.

We first selected four genes with potentially distinguishable tissue-specific profiles based on data detailed in the RiceXpro database [14, 15] (Supplemental Figure S3) in addition to OsSHR1, which is also predicted to be a stele-specific gene in RiceXpro: i) 5NG4, specifically expressed in the stele; ii) serine palmitoyltransferase $(S P)$, expressed in all tissues; iii) pollen Ole1 (PO), expressed in outer tissues (epidermis, exodermis, and sclerenchyma); and iv) disease resistance response protein $(D P)$, expressed in the cortex. We confirmed the strong stele-specific expression of the 5NG4 gene (Fig. 8b), 
Table 1 Primers and probes for digital RT-PCR

\begin{tabular}{|c|c|c|c|c|c|c|c|c|c|c|}
\hline Tissue & Position & Gene & $\begin{array}{l}\text { Primer } \\
\text { name }\end{array}$ & $\begin{array}{l}\text { Oligo } \\
\text { sequence }\end{array}$ & $\begin{array}{l}\text { Amplicon } \\
\text { size }\end{array}$ & $\begin{array}{l}\text { Probe } \\
\text { name }\end{array}$ & $\begin{array}{l}\text { Probe } \\
\text { sequence }\end{array}$ & $\begin{array}{l}\text { Tm } \\
\text { probe }\end{array}$ & Fluorophore & Reference \\
\hline \multirow[t]{6}{*}{ All } & \multirow[t]{2}{*}{$\begin{array}{l}\text { LOC_ } \\
\text { Os01g70380 }\end{array}$} & \multirow[t]{2}{*}{$\begin{array}{l}\text { Serine } \\
\text { palmitoyltransferase }\end{array}$} & Serine_F & $\begin{array}{l}\text { TTGCCG } \\
\text { TCGATAAT } \\
\text { CCTGAC }\end{array}$ & \multirow[t]{2}{*}{196} & \multirow[t]{2}{*}{ pSerine } & \multirow[t]{2}{*}{$\begin{array}{l}\text { CCTCGTTCGT } \\
\text { TCGTCGCT } \\
\text { GACGGC }\end{array}$} & \multirow[t]{2}{*}{64.2} & \multirow[t]{2}{*}{ HEX } & \multirow[t]{2}{*}{$\begin{array}{l}\text { Sato et al. } 2013 \\
\text { [15] }\end{array}$} \\
\hline & & & Serine_R & $\begin{array}{l}\text { GAGGAA } \\
\text { GAGG } \\
\text { TCGTCA } \\
\text { ATGG }\end{array}$ & & & & & & \\
\hline & \multirow[t]{2}{*}{$\begin{array}{l}\text { TFIIE (LOC_ } \\
\text { Os10g25770) }\end{array}$} & \multirow[t]{2}{*}{$\begin{array}{l}\text { Transcription factor } \\
2 \mathrm{E}\end{array}$} & TFIIE_F & $\begin{array}{l}\text { TTAGCTGT } \\
\text { GTTGGTCA } \\
\text { TGGG }\end{array}$ & \multirow[t]{2}{*}{161} & \multirow[t]{2}{*}{ pTFIIE } & \multirow[t]{2}{*}{$\begin{array}{l}\text { CGGAAGAGCT } \\
\text { GCTTCAGG } \\
\text { TCATCGTCG }\end{array}$} & \multirow[t]{2}{*}{63} & \multirow[t]{2}{*}{ HEX } & \multirow[t]{2}{*}{ This work } \\
\hline & & & TFIIE_R & $\begin{array}{l}\text { TCCCAG } \\
\text { GAGG } \\
\text { ACATTGTG } \\
\text { TA }\end{array}$ & & & & & & \\
\hline & \multirow[t]{2}{*}{$\begin{array}{l}\text { EXP' }^{\prime}(\mathrm{LOC} \\
\text { Os07g02340) }\end{array}$} & \multirow[t]{2}{*}{ Expressed } & Exp_F & $\begin{array}{l}\text { ATGG } \\
\text { GCAGAA } \\
\text { GTCGAA } \\
\text { GATG }\end{array}$ & \multirow[t]{2}{*}{155} & \multirow[t]{2}{*}{$\mathrm{pExp}$} & \multirow[t]{2}{*}{$\begin{array}{l}\text { AGCCAGCTTG } \\
\text { AGGCCAAC } \\
\text { AAGAAGGCC }\end{array}$} & \multirow[t]{2}{*}{64.9} & \multirow[t]{2}{*}{ HEX } & \multirow[t]{2}{*}{ This work } \\
\hline & & & Exp_R & $\begin{array}{l}\text { TाTGCACT } \\
\text { TGGTCT } \\
\text { CAGAGG }\end{array}$ & & & & & & \\
\hline \multirow[t]{4}{*}{ Stele } & \multirow[t]{2}{*}{$\begin{array}{l}\text { LOC_- } \\
\text { Os08g44750 }\end{array}$} & \multirow[t]{2}{*}{$\begin{array}{l}\text { Nodulin-like } \\
\text { protein }\end{array}$} & 5NG4_F & $\begin{array}{l}\text { GCAGAT } \\
\text { ATGG } \\
\text { TGCA } \\
\text { TCGACA }\end{array}$ & \multirow[t]{2}{*}{170} & \multirow[t]{2}{*}{ p5NG4 } & \multirow[t]{2}{*}{$\begin{array}{l}\text { GCCTCCCTCA } \\
\text { CCCTCGGC } \\
\text { GAGAGC }\end{array}$} & \multirow[t]{2}{*}{66.4} & \multirow[t]{2}{*}{ FAM } & \multirow[t]{2}{*}{$\begin{array}{l}\text { Sato et al. } 2013 \\
\text { [15] }\end{array}$} \\
\hline & & & 5NG4_R & $\begin{array}{l}\text { CCCAGA } \\
\text { GGAC } \\
\text { GAGG } \\
\text { TAGAG }\end{array}$ & & & & & & \\
\hline & \multirow{2}{*}{$\begin{array}{l}\text { OsSHR1 } \\
(\text { LOC__ } \\
\text { Os07g39820) }\end{array}$} & SHR1 & SHR1_F & $\begin{array}{l}\text { CAAGCC } \\
\text { GCCTCCG }\end{array}$ & 79 & pSHR1 & $\begin{array}{l}\text { CGTCCTACAA } \\
\text { CTCGAGG }\end{array}$ & 70 & HEX & $\begin{array}{l}\text { Henry et al. } 2017 \\
\text { [16] }\end{array}$ \\
\hline & & & SHR1_R & $\begin{array}{l}\text { TGGACC } \\
\text { CGCT } \\
\text { CGAC }\end{array}$ & & & & & & \\
\hline Cortex & $\begin{array}{l}\text { LOC_ } \\
\text { Os10g18820 }\end{array}$ & $\begin{array}{l}\text { Plant disease } \\
\text { response protein }\end{array}$ & Dis_F & $\begin{array}{l}\text { AAGGGA } \\
\text { TCCACACT } \\
\text { TCAGGT }\end{array}$ & 152 & pDis & $\begin{array}{l}\text { GCTGCAAGCA } \\
\text { GTGGTGAG } \\
\text { TGGTCTGTT }\end{array}$ & 63.2 & FAM & $\begin{array}{l}\text { Sato et al. } 2013 \\
\text { [15] }\end{array}$ \\
\hline & & & Dis_R & $\begin{array}{l}\text { AGTTCT } \\
\text { CGAA } \\
\text { CAGCAT } \\
\text { CCTC }\end{array}$ & & & & & & \\
\hline & $\begin{array}{l}\text { LOC_ } \\
\text { Os06g48950 }\end{array}$ & OsARF19 & $\begin{array}{l}\text { OsARR19_ } \\
\mathrm{F}\end{array}$ & $\begin{array}{l}\text { TCCTCAGA } \\
\text { CTCAGA } \\
\text { ACACCA }\end{array}$ & 177 & pARF19 & $\begin{array}{l}\text { TGCCTGGGCT } \\
\text { GAGCTTGG } \\
\text { TTCAGTGG }\end{array}$ & 64.6 & FAM & $\begin{array}{l}\text { Yamauchi et al. } \\
2019 \text { [17]; } \\
\text { Takehisa et al. } \\
2012 \text { [1] }\end{array}$ \\
\hline & & & $\begin{array}{l}\text { OsARR19_ } \\
\mathrm{R}\end{array}$ & $\begin{array}{l}\text { GGTTCT } \\
\text { GCAG } \\
\text { GCATAATT } \\
\text { GC }\end{array}$ & & & & & & \\
\hline & $\begin{array}{l}\text { LOC_ } \\
\text { Os01g60960 }\end{array}$ & OsLBD1-8 & $\begin{array}{l}\text { OsLBD1- } \\
\text { 8_F }\end{array}$ & $\begin{array}{l}\text { CGTC } \\
\text { CAAGTC } \\
\text { CATATCAC } \\
\text { CG }\end{array}$ & 198 & $\begin{array}{l}\text { pLBD1- } \\
8\end{array}$ & $\begin{array}{l}\text { CTTCGCCGCT } \\
\text { СCTCCTCC } \\
\text { TCCTCC }\end{array}$ & 66.4 & FAM & $\begin{array}{l}\text { Yamauchi et al. } \\
2019 \text { [17] }\end{array}$ \\
\hline & & & $\begin{array}{l}\text { OsLBD1- } \\
8 \_R\end{array}$ & $\begin{array}{l}\text { TTGAGG } \\
\text { GAGC } \\
\text { TGTAGTCA } \\
\text { GT }\end{array}$ & & & & & & \\
\hline Outer & $L O C_{-}$ & Pollen Ole 1 & Ole_F & ТTCTACTT & 179 & pOle & GGACGGTGCC & 65.2 & FAM & Sato et al. 2013 \\
\hline
\end{tabular}


Table 1 Primers and probes for digital RT-PCR (Continued)

\begin{tabular}{|c|c|c|c|c|c|c|c|c|c|c|}
\hline Tissue & Position & Gene & $\begin{array}{l}\text { Primer } \\
\text { name }\end{array}$ & $\begin{array}{l}\text { Oligo } \\
\text { sequence }\end{array}$ & $\begin{array}{l}\text { Amplicon } \\
\text { size }\end{array}$ & $\begin{array}{l}\text { Probe } \\
\text { name }\end{array}$ & $\begin{array}{l}\text { Probe } \\
\text { sequence }\end{array}$ & $\begin{array}{l}\text { Tm } \\
\text { probe }\end{array}$ & Fluorophore & Reference \\
\hline & \multirow[t]{2}{*}{ Os10g39890 } & \multirow[t]{2}{*}{ allergen } & & $\begin{array}{l}\text { CACCCTGT } \\
\text { CCCA }\end{array}$ & & & \multirow[t]{2}{*}{$\begin{array}{l}\text { ACCTACTG } \\
\text { ATCGACCGT }\end{array}$} & & & \multirow[t]{2}{*}{ [15] } \\
\hline & & & Ole_R & $\begin{array}{l}\text { ACAAAG } \\
\text { GCCA } \\
\text { AACAAC } \\
\text { ACAC }\end{array}$ & & & & & & \\
\hline & \multirow[t]{2}{*}{$\begin{array}{l}\text { LOC_- } \\
\text { Os02g06290 }\end{array}$} & \multirow[t]{2}{*}{ OsHAC4 } & $\begin{array}{l}\text { OsHAC4_ } \\
\mathrm{F}\end{array}$ & $\begin{array}{l}\text { GGAAGG } \\
\text { AGAA } \\
\text { GAACCC } \\
\text { ACAC }\end{array}$ & 188 & pHAC4 & \multirow[t]{2}{*}{$\begin{array}{l}\text { AGGTGTGCGA } \\
\text { TCCAGGCT } \\
\text { CGCGA }\end{array}$} & \multirow[t]{2}{*}{64.5} & FAM & \multirow[t]{2}{*}{$\begin{array}{l}\text { Xu et al. } 2017 \\
\text { [18] }\end{array}$} \\
\hline & & & $\begin{array}{l}\text { OsHAC4_ } \\
\mathrm{R}\end{array}$ & $\begin{array}{l}\text { CTGGCTIT } \\
\text { CA } \\
\text { CTTCGG } \\
\text { AGAA }\end{array}$ & & & & & & \\
\hline & \multirow[t]{2}{*}{$\begin{array}{l}\text { LOC_ } \\
\text { Os06g44970 }\end{array}$} & \multirow[t]{2}{*}{ OsPIN2 } & OsPIN2_F & $\begin{array}{l}\text { CCAGAG } \\
\text { CGTC } \\
\text { ATCTGGTA } \\
\text { CA }\end{array}$ & 80 & pPIN2 & \multirow[t]{2}{*}{$\begin{array}{l}\text { CCCTCATGCT } \\
\text { CTTCCTCTTCG }\end{array}$} & \multirow[t]{2}{*}{63.6} & FAM & \multirow[t]{2}{*}{$\begin{array}{l}\text { Wang et al. } 2018 \\
\text { [19] }\end{array}$} \\
\hline & & & OsPIN2_R & $\begin{array}{l}\text { GGAACT } \\
\text { GCTC } \\
\text { GGAG } \\
\text { ATGAG }\end{array}$ & & & & & & \\
\hline
\end{tabular}

whereas $S P, D P$ and $P O$ were weakly expressed in this tissue (Fig. 8c, d and e). As expected, PO appeared to be expressed in the epidermis/exodermis (Fig. 8e), SP was expressed at the same low level in all the tissues (Fig. $8 \mathrm{c}$ ), and DP appeared to be weakly expressed in cortex and outer cell layers (epidermis/exodermis/sclerenchyma) (Fig. 8d). Very few positive droplets in water are often visible for some probes (i.e., 5NG4 and OsSHR1), while droplets are missing in water control for others such as EXP' even though the gene is highly expressed,
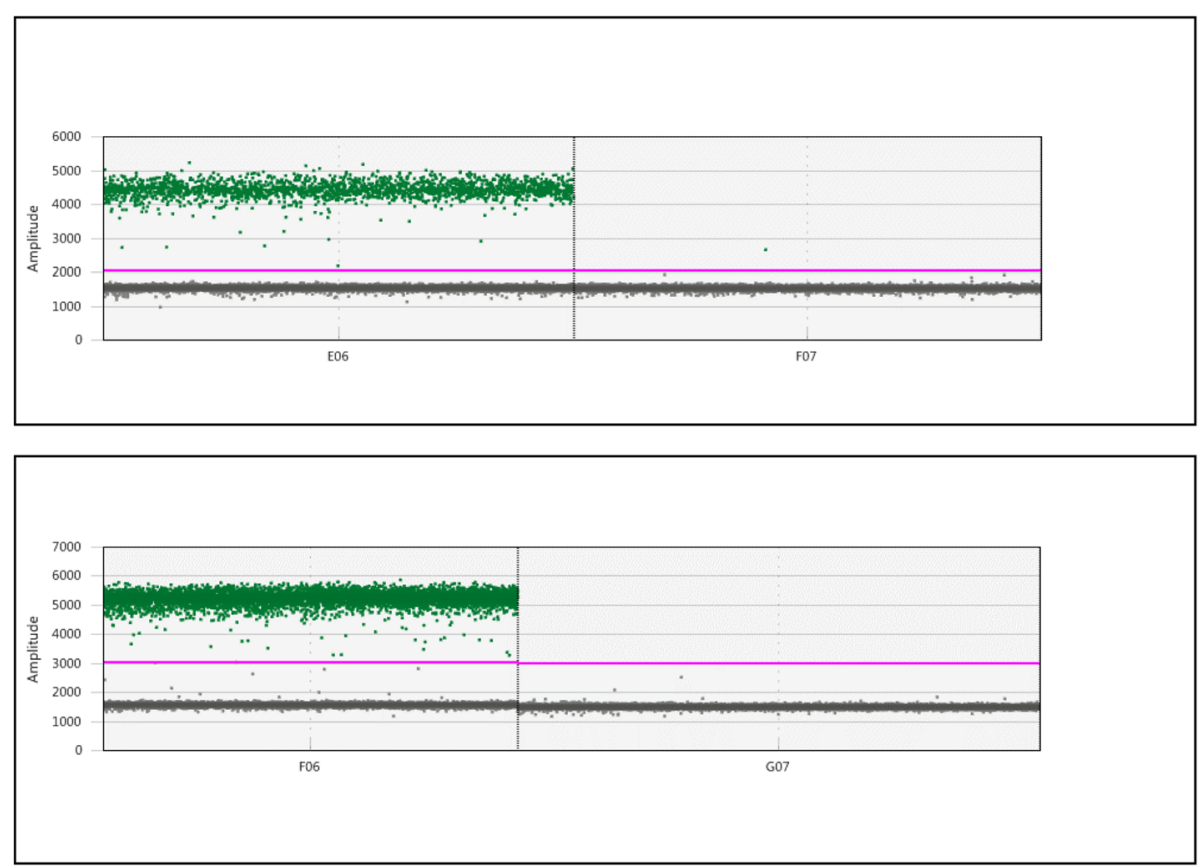

Fig. 6 Validation of constitutive control for ddRT-PCR. One-dimensional diagrams of ddRT-PCR for TFIIE (up) and Exp' (down). The red bar shows the threshold for detection of a positive droplet. One nanogram of root RNA was used as the input on the right image. The left image corresponds to negative control without RNA 


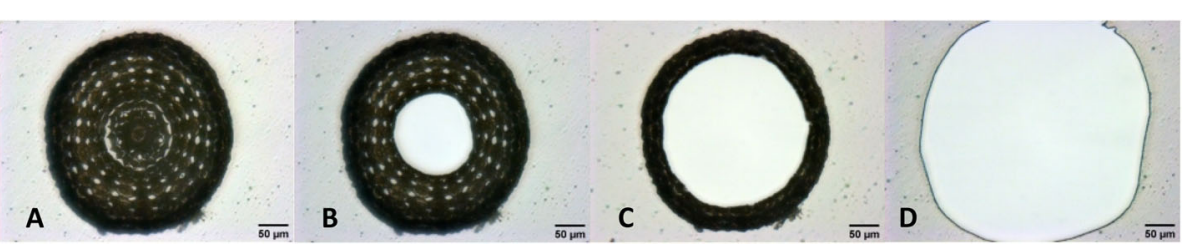

Fig. 7 Microdissection of root tissues. a-d Cutting of the root tissues by microdissection; the tissues are extracted successively from the inside to the outside. a A paraffin section before cutting. b After cutting the stele + endodermis. c After cutting the cortex. $\mathbf{d}$ After cutting the external tissues, epidermis/exodermis and sclerenchyma

suggesting that these few positive droplets more likely result from autohydrolysis of the Taqman probe than from RNA or cDNA contamination of water. The four genes were initially selected due to their similar expression levels, which equaled approximately 1000-2000 as estimated by microarray signals and detailed in the RiceXpro database [14, 15] (Fig. 8 and Supplemental
Figure S3), but a poor correlation was found between the levels included in the RiceXpro database and the real expression levels [14, 15].

We performed two RT-ddPCR experiments to estimate the relative expression levels of the $5 N G 4$ gene (FAM probe) among the stele, cortex and external tissues using the TFIIe and EXP' genes (HEX probe) (Fig. 9)
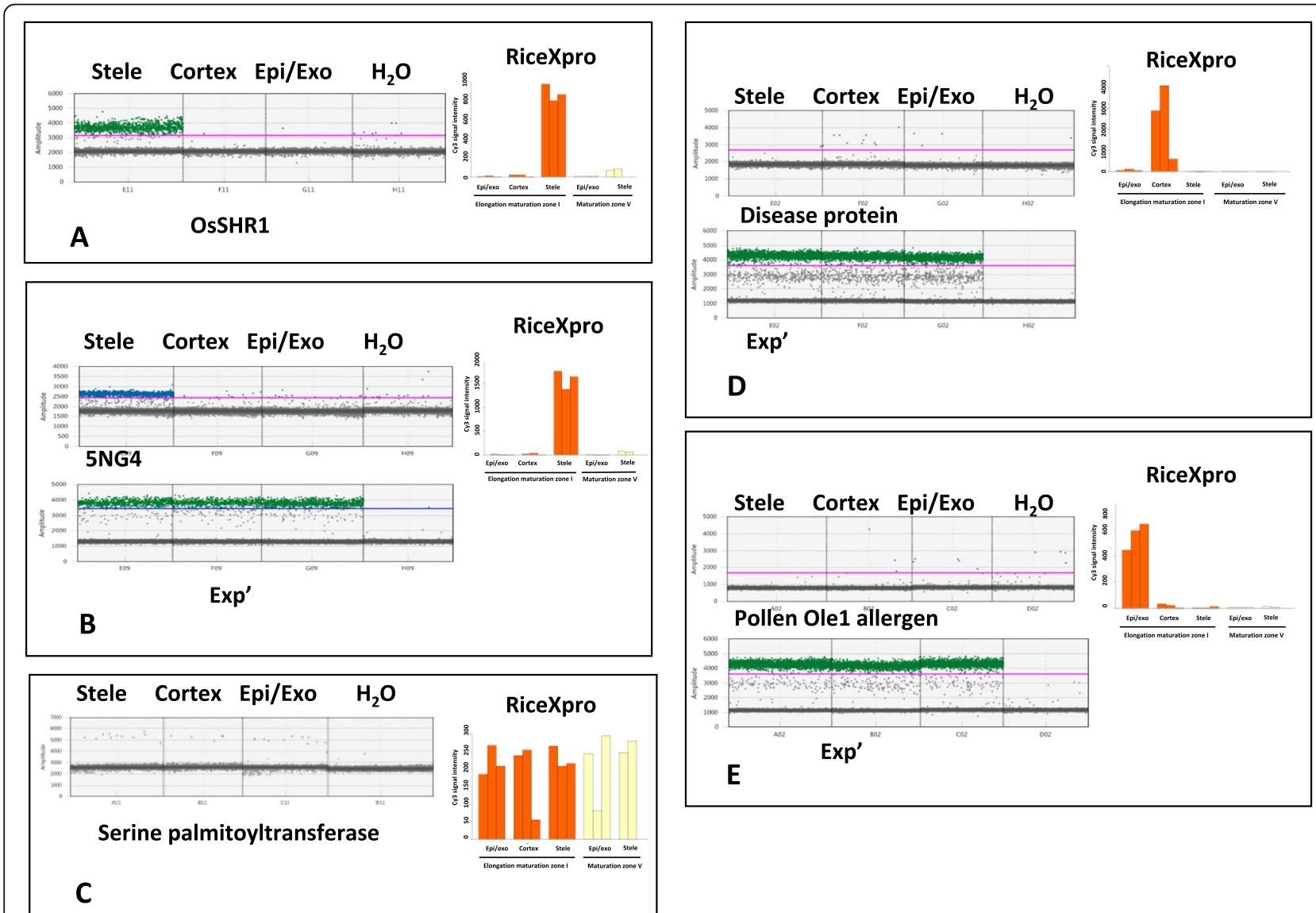

Fig. 8 Expression profiling of candidate genes identified from RiceXpro in root tissues using RT-ddPCR. One-dimensional diagrams of ddRT-PCR for OsSHR1 (a), 5NG4 (b), serine palmitoyltransferase (c), disease resistance response protein $(\mathbf{d})$ and pollen Oel (e) in three tissues (stele, cortex, and epidermis/exodermis) and a negative control $\left(\mathrm{H}_{2} \mathrm{O}\right)$. The expression profiles extracted from the RiceXpro database are shown in parallel. OsSHR1 was used as a positive control of stele-specific expression. EXP' was used as a constitutive control for ddRT-PCR, excepted for OsSHR1 and serine palmitoyltransferase as the probes for these two genes had the same FAM fluorophore as EXP' 

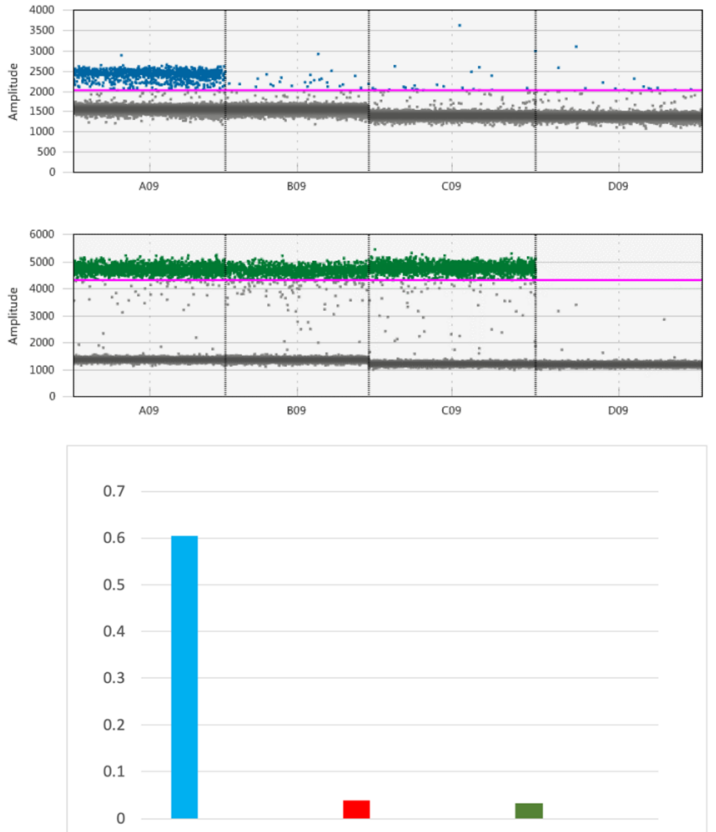

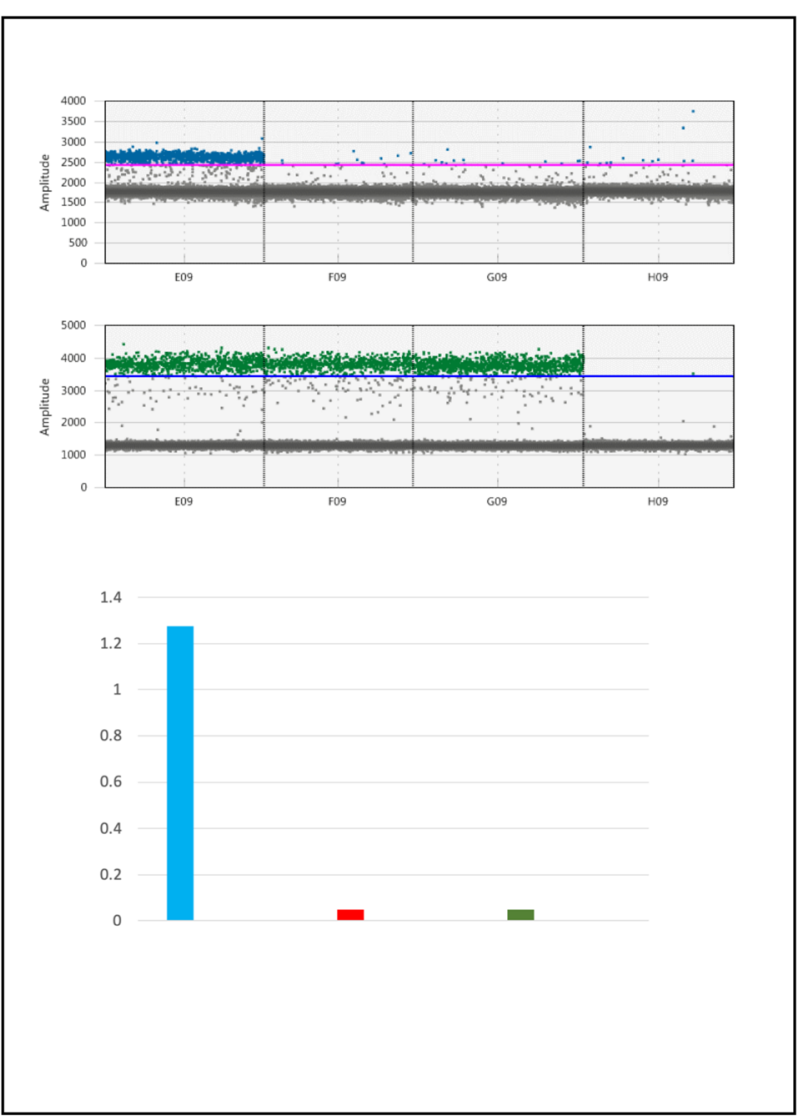

Fig. 9 Relative expression profiling of 5NG4 in the stele, cortex and epidermis/exodermis using TFIIE and EXP' for normalization of RNA quantity. 1D diagram of ddRT-PCR for 5NG4 expression in three tissues (stele, cortex and epidermis/exodermis) and a negative control (water) using EXP' (a) and TFlle (b) for normalization. Blue, FAM probes; green, HEX probes. Bottom, relative expression levels in the three tissues after normalization with EXP' (left) or TFIIE (right). The abscises represent arbitrary expression values

as normalization controls. $5 N G 4$ is preferentially expressed in the stele but is also expressed at a detectable level in other tissues. Normalization using EXP' showed that the 5NG4 expression level in the cortex and outer tissues was 15- and 18-fold lower than that in the stele. In contrast, normalization using TFIIe revealed that the 5NG4 expression level in the cortex and external tissues was 26- and 25-fold lower than that in the stele.

To identify new tissue-specific markers, we searched the bibliography sources for candidate genes with expression profiles specific to either external tissues or the cortex and expression in the root tip. In a recent article, the OSARF19 and OsLBD1-8 genes have been described as mainly and strongly expressed in the root cortex [17]. Moreover, these genes appear to play an important role in the formation of root aerenchymas through auxin action. The authors also used LM to separate the cortex from the stele but did not isolate the outer tissues. We wanted to confirm the cortex-specific majority expression profiles of $L B D 1-8$ and $A R F 19$ and to verify whether they were expressed in external tissues. We did not detect the expression of $L B D 1-8$ in our conditions (Fig. 10a). In [17], the $L B D 1-8$ gene is described as mainly expressed between 0 and $5 \mathrm{~mm}$ from the root tip and mainly in the cortex beyond $18 \mathrm{~mm}$. We did not find detectable expression of $L B D 1-8$ (Fig. 10a), which can be explained by the different growing conditions and by the different area sampled for LM in our conditions compared to [17]. ARF19 expression was detected under our conditions with a similar expression profile between cortex, stele and external tissues (Fig. 10b). ARF19 does not appear to be mainly and specifically expressed in the cortex, at least not in the first $15 \mathrm{~mm}$ of the root tip, under our conditions (Fig. 10b). Therefore, we can conclude that $L B D 1-8$ and $A R F 19$ are not cortex-specific markers in our conditions.

We also analyzed the expression of two genes with potentially specific expression profiles in external tissues and root tips, OsHAC4 and OsPIN2. OsHAC4 plays a role in tolerance to arsenic in rice [18] and appears to be strongly expressed in the expidermis and exodermis, at least in experiments using GUS promoter fusions. Under our conditions, OsHAC4 was expressed specifically but 

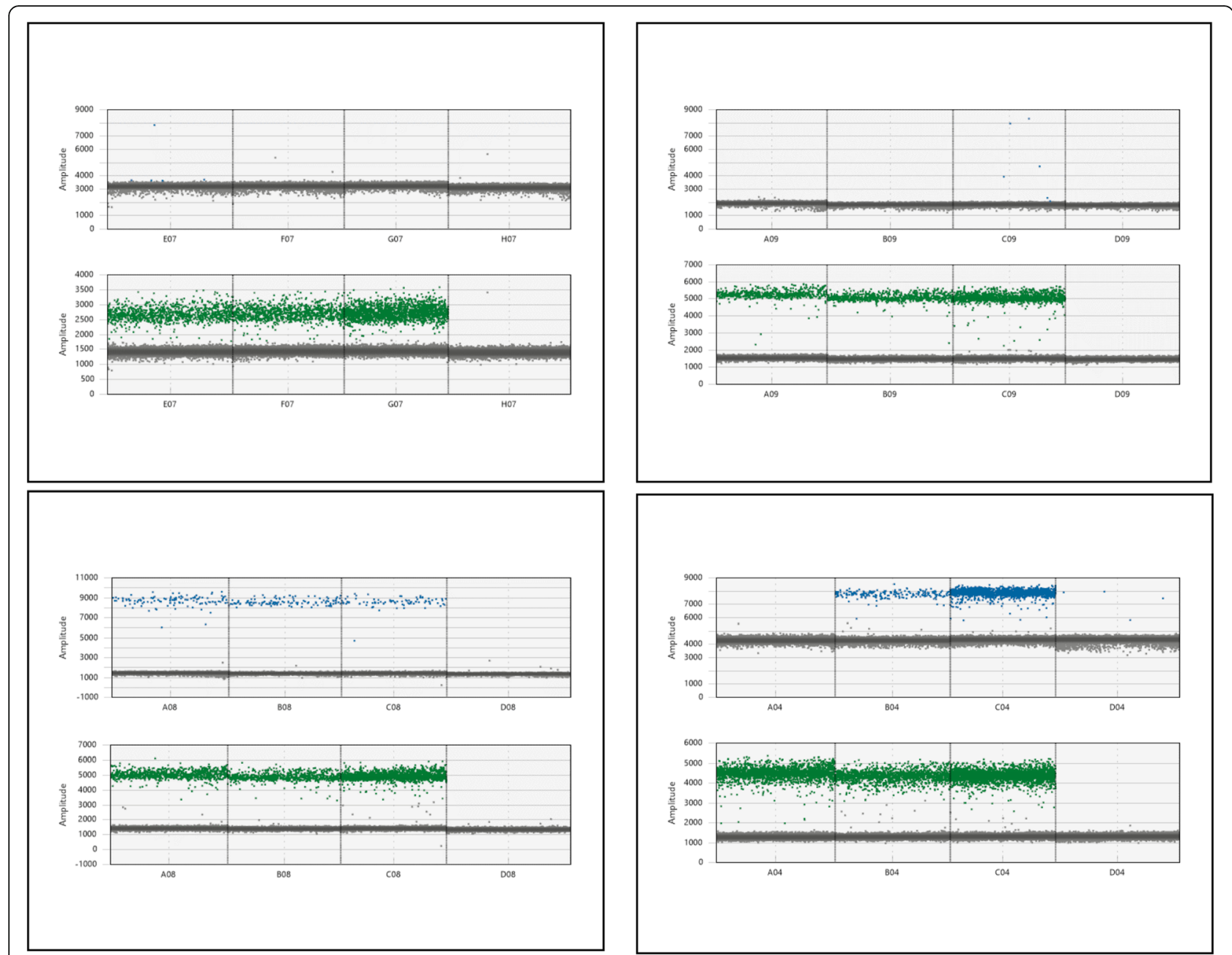

Fig. 10 Expression profiling of candidate genes identified from bibliography sources. One-dimensional diagrams of ddRT-PCR for OSLBD1-8 (a), $\operatorname{OSARF19}(\mathbf{b})$, OsHAC4 (c), and OsPIN2 (d) in three tissues (stele, cortex, and epidermis/exodermis) and a negative control $\left(\mathrm{H}_{2} \mathrm{O}\right)$. EXP' was used as a constitutive control for ddRT-PCR

at low levels in outer tissues (Fig. 10c). We also analyzed the expression of OsPIN2, which has been described to be mainly and highly expressed in external tissues with some expression in the cortex [19]. We confirmed these results. OsPIN2 is strongly expressed in external tissues and at a lower level in the cortex (Fig. 10d) but is absent from stele tissues.

In conclusion, we confirmed only stele-specific expression of 5NG4 and SHR1. The other tested genes have either a very low level of expression (OsHAC4) or were expressed in at least two tissues with similar expression levels. Other genes from RiceXpro may need to be screened, or RNAseq libraries may need to be built to identify and test potential new tissue-specific markers. Nevertheless, our combination of ddRT-PCR and LM facilitated easy and rapid quantitative expression profiling for ten genes in rice tissues.

\section{Sensitivity of ddRT-PCR and RT-qPCR}

To test the sensitivity of the RT-ddPCR method, we performed serial dilutions of total root RNA to obtain RNA amounts ranging from $1 \mathrm{ng}$ to $1 \mathrm{fg}$ (Fig. 11). We detected the expression of the EXP' gene from RNA samples containing at least $100 \mathrm{fg}$ (only one positive droplet was observed with the sample containing $100 \mathrm{fg}$ of RNA). A perfect linear relationship was detected between the number of positive droplets and the amount of RNA or copy number per microliter up to an RNA amount of $10 \mathrm{pg}$ (Fig. 11). 5NG4 gene expression was also detected from samples containing at least $10 \mathrm{pg}$ of RNA, and a perfect linear relationship was found between the number of positive droplets and the amount of RNA or the number of copies per microliter. In contrast, $100 \mathrm{pg}$ of RNA was necessary for the detection of OsSHR1 expression. 


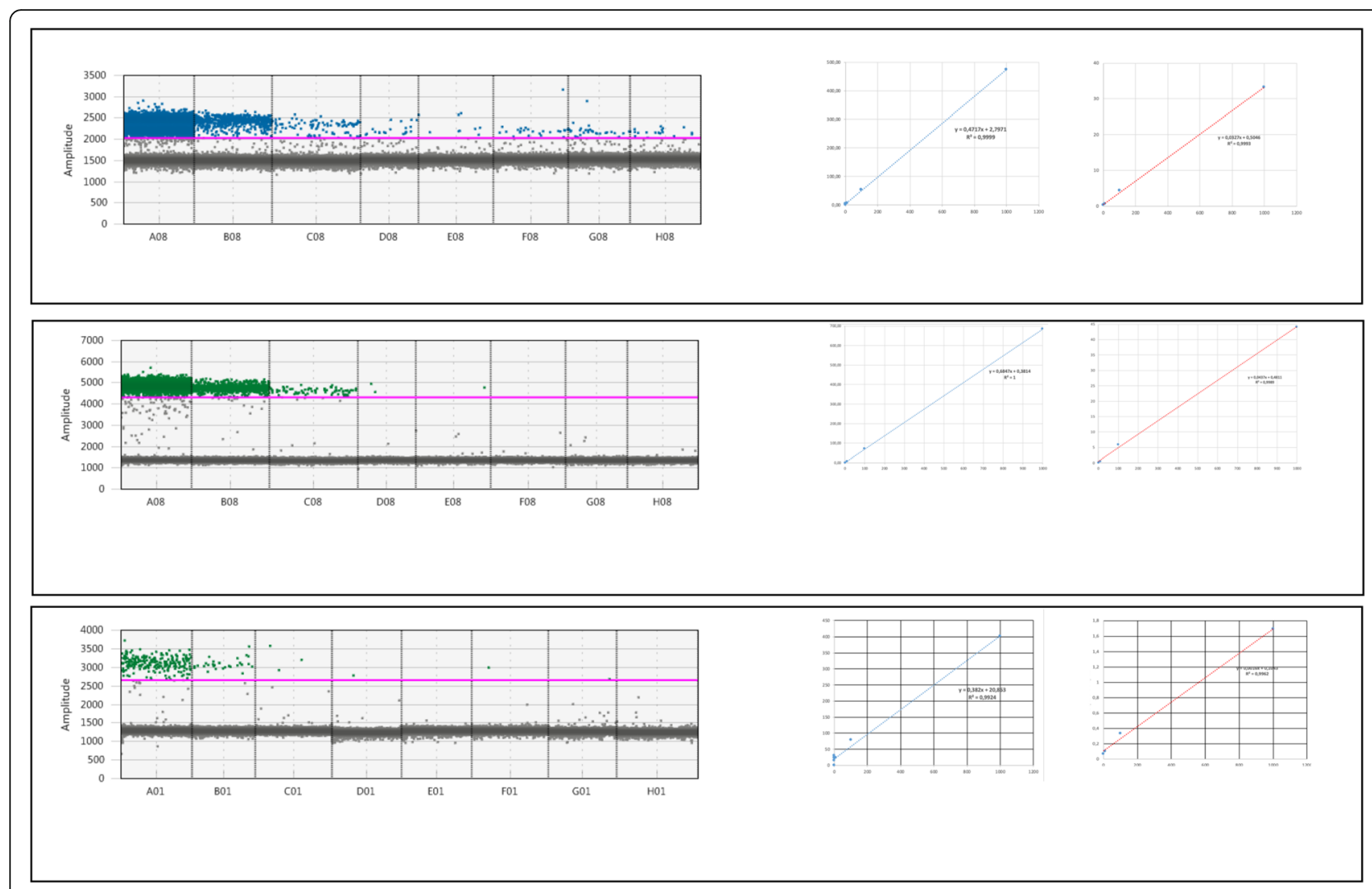

Fig. 11 ddRT-PCR for 5NG4 A), EXP'B) and OsSHR1 C) using serial dilutions of total root RNA. Left, 1D diagram of ddRT-PCR for 5NG4, EXP' and OsSHR1 in serial dilutions of total root RNA ranging from $1 \mathrm{ng}$ to $1 \mathrm{fg}$ and in a negative control $\left(\mathrm{H}_{2} \mathrm{O}\right)$. Right, diagrams showing the correlations of the percentages of positive droplets or copies per microliter with the amount (pg) of RNA per reaction. Red bar, threshold for droplet detection

We also tested the sensitivity of qRT-PCR for the EXP' and SHR1 genes using a range of dilutions using the same TaqMan probes and the same primer pairs for comparison with ddRT-PCR (Supplemental Figure S5). For SHR1, a linear relationship between $\mathrm{Ct}$ values and the amount of RNA in pg was found between $250 \mathrm{ng}$ and $100 \mathrm{pg}$ for qRT-PCR. For EXP', a linear relationship between $\mathrm{Ct}$ values and the amount of RNA in pg was found up to $10 \mathrm{pg}$ (Supplemental Figure S5).

Although the sensitivity of ddRT-PCR appears to be better by a factor of approximately 10 , caution should be exercised as the sensitivity thresholds between these methods remain close. Therefore, qRT-PCR using TaqMan probes is a possible alternative for relative quantification of expression profiles between tissues with lower sensitivity. In addition to better sensitivity, calibration curves are not required for ddRT-PCR, allowing absolute quantification of the number of RNA molecules for a given gene.

Using the proposed protocol, root tissue RNA from three biological repeats and 30 rice roots can be collected within 1 week by one individual. Moreover, expression profiling can be completed in one week using ddRT-PCR for at least 10 genes, demonstrating that the combination of RT-ddPCR and LM is complementary to in situ RT-PCR and in situ hybridization for tissue expression profiling.

\section{Discussion}

A simple and rapid protocol for preparing paraffin blocks and performing $\mathrm{LM}$ of root tissues

Using our protocol, it is possible to obtain high-quality RNA from rice root tissue that is suitable for downstream applications, such as RT-ddPCR or RNAseq, within 3 days. Compared with the reference protocols [9], we used thicker and fewer tissue sections with high RNA quality suitable for RT-ddPCR and RNAseq.

One of the critical issues for LM is preservation of the tissue structure. Cryosectioning is often preferred to paraffin-embedded specimens because the activity of RNases is reduced despite preservation of the tissue structure (see for instance [22]). In addition, the use of foam has reduced degradation during the inclusion steps, probably due to mechanical shocks (see Figs. 1 and 2). Furthermore, reducing paraffin impregnation times from $30 \mathrm{~min}$ to $10 \mathrm{~min}$ also facilitated preservation of the structure of the root tissues (see Figs. 3 and 4) compared to a reference protocol [9]. Moreover, we 
provide a full detailed protocol with the key points that should be optimized by other research groups to adapt the protocol to other tissue/species. In addition to these specific points, cold dehydration and the use of methanol instead of water for mounting the slides are also important parameters to consider (see also Supplemental Figure S2 for more details).

Moreover, paraffin usually preserves the tissue structure better than freezing medium, and paraffin blocks can also be used for other complementary applications, such as in situ hybridization and immunochemistry, to compare, for instance, mRNA and protein localization if required [16]. For example, archiving of paraffin blocks has been used for tumor samples [23] in biomedical research, which is a critical point for crop species such as rice because this feature enables sample collection in the field and storage before analysis in a distant laboratory for agronomical or plant pathology analyses.

Our proposed protocol is a high-throughput approach, and as a result, the protocol allows sample collection and RNA extraction from 100 root sections within 1 or 2 weeks for downstream applications such as RNAseq and ddRT-PCR. The proposed protocol can be used for a broad list of plant species with minimal modifications and/or optimization.

\section{A simple and efficient protocol that is complementary to in situ hybridization and/or in situ RT-PCR}

One of the key experiments for characterizing gene or gene network function involves clarification of the tissue expression of candidate genes. This analysis is usually achieved through promoter fusion and/or in situ hybridization and in situ RT-PCR [24]. The former approach can only be applied for species for which genetic transformation approaches have been developed, and the latter is laborious and probe dependent. In addition, in situ RT-PCR is a notably less popular approach [24]. Tissue-specific RNA extraction offers an attractive alternative but was not considered until now as a true alternative because its reproductivity and technicity hampered its widespread use, particularly in combination with qPCR. Here, we provide a substantially simpler and reproductible protocol that should help any research laboratory aiming to perform tissue-specific expression profiling of plant tissues by ddRT-PCR as well as other downstream applications, such as RNAseq.

For this purpose, we validated three of four candidate genes detailed in the RiceXpro database [14, 15]. Moreover, we quantitatively analyzed the expression of OsSHR1 and demonstrated that this gene is also expressed outside stele tissue, albeit at a much lower level. The expression levels observed by RT-ddPCR (Fig. 8 and Supplemental Figure 3) differ significantly from the levels estimated by microarray $[14,15]$, and the use of RT-ddPCR provides an absolute and more realistic estimate of the tissue-specific transcription level. We also tested the tissue specificity of OsARF19 and LBD1-8, which are described as being specifically expressed in the cortex [17], and OsPIN2 and OsHAC4, which are specifically expressed in outer cell layers based on [18, 19]. We confirmed the specificity of expression in outer cells for OsHAC4 despite a very low expression level (Fig. 10c) and the strong expression of OsPIN2 in outer tissues. OsPIN2 expression was also detected in the cortex but at a lower level than in outer layers. We observed very similar expression profiling in our results (Fig. 10d). Altogether, with only 30 microdissected root sections, we were able to complete expression profiling of twelve genes and estimate their relative expression levels in three root tissues.

This protocol will clearly help democratize the technologies for plant applications and should help researchers better understand tissue- and cell-specific responses during plant development or in response to changing environmental conditions, including pathogen/ biostimulant interactions. Our future objective is to build on this work and perform a transcriptomic analysis of the formation of root tissues in rice and identify the gene network involved in aerenchyma formation.

\section{Conclusions}

The protocol developed in this study and the detailed troubleshooting guide provided should allow research laboratories to develop and democratize LM-based tissue-specific approaches combined with RT-ddPCR for the analysis of plants. Thus, the proposed protocol will offer an alternative method for the identification and characterization of cell- and tissue-specific responses. Because the starting materials are embedded in paraffin, the samples can be stored for a long time for additional experiments to confirm the results or provide more precise insights using complementary technologies, such as in situ approaches, if needed. Using rice root tissues as an example, we showed that this protocol coupling LM and RT-ddPCR can be used to characterize the tissuespecific responses of the transcription factor OsSHR1 and to perform tissue-specific expression profiling of twelve candidate genes within less than 2 weeks.

\section{Methods}

\section{Plant material and growth conditions}

Nipponbare seeds were initially ordered from the $\mathrm{Na}$ tional Bioresource center (https://shigen.nig.ac.jp/rice/ oryzabase/about/nbrpRice) and then multiplied in greenhouses in Montpellier. Two hundred dehusked seeds of Oryza sativa cv Nipponbare were surface-sterilized in $50 \mathrm{~mL}$ of $70 \%$ ethanol for $2 \mathrm{~min}$, rinsed with $50 \mathrm{~mL}$ of sterile Milli-Q water and disinfected by dipping in a 50 - 
$\mathrm{mL} 40 \%$ bleach solution $\left(9.6^{\circ} \mathrm{Cl}\right)$ diluted with distilled water containing 0.4\% Tween 80 (Sigma-Aldrich P4780$500 \mathrm{~mL}$ ) for $30 \mathrm{~min}$ under gentle agitation at room temperature. The seeds were then rinsed seven times with $40 \mathrm{~mL}$ of distilled water. Fifty seeds were added per petri dish $(90 \times 14 \mathrm{~mm})$ containing Whatman paper prewetted with $8 \mathrm{~mL}$ of Milli-Q. Petri dishes were sealed with parafilm and incubated overnight at $28^{\circ} \mathrm{C}$ in a growth chamber (12-h light/12-h dark cycle). Four 6-L buckets and floating sieves were disinfected overnight with $12 \% \mathrm{H}_{2} \mathrm{O}_{2}$ at room temperature. The entire system was rinsed generously with sterile water. The buckets were filled with osmosis water, and the floating sieves were placed in the buckets. Twenty seeds/sector (four sectors) were added at $3 \mathrm{pm}$ after $30 \mathrm{~h}$ of incubation on petri dishes. The seedlings were grown hydroponically (ARALAB, FitoClima 600) in osmotic water for 7 days (see Table 2 for the light/hygrometric conditions and also Supplemental Figure S1). The program is detailed below. The light cycle was started at $10 \mathrm{am}$, allowing $5 \mathrm{~h}$ of heating from the time that the lamps were switched on to the time of sample collection (at $3 \mathrm{pm}$ ). The detailed program (60\% humidity, temperatures of $28^{\circ} \mathrm{C}$ during the day and $24{ }^{\circ} \mathrm{C}$ at night) is as follows: Segment 0 ; Segment 1: Increase the brightness to $10 \%$ over $1 \mathrm{~min}$; Segment 2: Increase the brightness to $90 \%$ over $59 \mathrm{~min}$; Segment 3: Maintain the brightness at $90 \%$ for $10 \mathrm{~h}$ (if sowing at $3 \mathrm{pm}$, start the cycle with Segment 3 at 240 min); Segment 4: Decrease the brightness to $10 \%$ over 1 $\mathrm{h}$; Segment 5: Decrease the brightness to $0 \%$ over $12 \mathrm{~h}$; Segment 6: Return to Segment 1.

\section{Sample collection and fixation}

All commercial reagents and product references are detailed in Table 3. All steps must be performed under RNase-free conditions. An aluminum sheet was placed on the work surface, gloves and containers should be successively washed with RNaseZAP, ethanol, RNaseZAP and ethanol, and the same procedure should be used for the LM microscope, three small Histos beakers with their covers, one rack for the Histos 5 cassette, and three magnetic stirrers. A large Histos beaker should be prepared to serve as a water bath. All materials should be placed in an oven at $54^{\circ} \mathrm{C}$. The EAA solution (ethanol:acetic acid fixing solution 3:1) $(>200 \mathrm{~mL})$ should be

Table 2 ARALAB conditions for rice seedling growth

\begin{tabular}{llll}
\hline Time & Temperature & Humidity & Light intensity \\
\hline 720 min & $23^{\circ} \mathrm{C}$ & $60 \%$ & $0 \%$ \\
$1 \mathrm{~min}$ & $27{ }^{\circ} \mathrm{C}$ & $60 \%$ & $10 \%$ \\
$59 \mathrm{~min}$ & $27^{\circ} \mathrm{C}$ & $60 \%$ & 10 to $90 \%$ \\
$600 \mathrm{~min}$ & $27^{\circ} \mathrm{C}$ & $60 \%$ & $90 \%$ \\
$60 \mathrm{~min}$ & $27^{\circ} \mathrm{C}$ & $60 \%$ & 90 to $10 \%$ \\
\hline
\end{tabular}

prepared and maintained under cold conditions. A volume of $120 \mathrm{~mL}$ of the following dehydration solutions was prepared in advance: $75,80,8590,95$, and $100 \%$ absolute ethanol, ethanol:butanol 1:1 (v/v) and 100\% butanol $100 \%$. Then, $150 \mathrm{~mL}$ of butanol:paraffin 1:1 (v/v) was added, and the next day, $75 \mathrm{~mL}$ of butanol and $75 \mathrm{~mL}$ of melted paraffin were added at $56^{\circ} \mathrm{C}$ (see below). These solutions were stored overnight at $4{ }^{\circ} \mathrm{C}$, except for butanol:paraffin, which should be stored at $54^{\circ} \mathrm{C}$. The EAA solution was distributed into four $30-\mathrm{mL}$ tubes plus two $40-\mathrm{mL}$ tubes. One milliliter of $2 \%$ eosin was added to two of the $30-\mathrm{mL}$ fixing solution tubes and to one of the 40-mL fixing solution tubes. A large Histos beaker serving as a water bath was filled with distilled water and stored at $45^{\circ} \mathrm{C}$. Root tips with a length of $1.5 \mathrm{~cm}$ were hand-dissected in $10 \mathrm{~mL}$ of cold $\left(4^{\circ} \mathrm{C}\right)$ RNAsecure reagent-treated water (AM7005, Thermo Fischer Scientific, USA) and placed in $40 \mathrm{~mL}$ of cold EAA solution. Several root samples were transferred in EAA with $2 \%$ eosin solution to serve as visual controls and to allow orientation of the root sections during cutting in the paraffin blocks. After sample harvest, the EAA solution was replaced by fresh solution and vacuum infiltrated for $5 \mathrm{~min}(0.6 \mathrm{psi})$. The EAA solution was replaced again with fresh solution, and the samples were incubated overnight at $4{ }^{\circ} \mathrm{C}$.

\section{Tissue dehydration and embedding (see also Supplemental Figure S4)}

The next day, the paraffin-embedding station and Histos 5 were switched on and cleaned in advance. A volume of $150 \mathrm{~mL}$ of paraffin was added to two of the beakers maintained at $54{ }^{\circ} \mathrm{C}$. The butanol:paraffin solution was heated at $54{ }^{\circ} \mathrm{C}$. The biopsy cassettes were transferred in a glass petri dish filled with cold $75 \%$ ethanol. Biopsy foam (M476-1, Simport, Canada) was added on the cassette $(1,267,796$ Thermo Scientific, USA). The roots were very carefully placed on the first foam such that all the root tips were aligned without any stacking. Three bundles of roots were added per cassette, with each bundle containing seven roots. An eosin-stained root was added per bundle. A second biopsy foam was put on the roots before closing the cassette.

The samples were then subjected to 5 -min baths with increasing ethanol concentrations $(75,80,85,90,95$ and $100 \%$ ), one 10 -min bath in an ethanol/butanol (1:1) solution and one 10-min bath in absolute butanol. The samples were transferred to a water bath at $54{ }^{\circ} \mathrm{C}$ and then to a histology microwave oven (Histos 5 Rapid Tissue Processor, Milestone, Italy). The samples were then subjected to a 5-min bath in butanol/paraffin (1:1) solution at $54{ }^{\circ} \mathrm{C}$ and $300 \mathrm{~W}$ and then two 5 -min baths in paraffin at $54{ }^{\circ} \mathrm{C}$ and $250 \mathrm{~W}$. Prior to the embedding step, the root bundles were rapidly removed from the cassettes 
Table 3 Reagents and materials

\begin{tabular}{|c|c|c|c|}
\hline Reagent & Chemical formula & Source & Identifier \\
\hline Absolute ethanol & $\mathrm{C}_{2} \mathrm{H}_{5} \mathrm{OH}$ & Honeywell, USA & 603-002-00-5 \\
\hline Acetic acid & $\mathrm{C}_{2} \mathrm{H}_{4} \mathrm{O}_{2}$ & WWR, USA & $0714-2.5 \mathrm{~L}$ \\
\hline Butanol & $\mathrm{CH}_{3}-\mathrm{CH}_{2}-\mathrm{CH}_{2}-\mathrm{CH}_{2} \mathrm{OH}$ & Sigma-Aldrich, USA & B7906-500 ml \\
\hline Leica-Paraplast XTRA & & Leica, Germany & $39,603,002$ \\
\hline Xylene & $\mathrm{C} 6 \mathrm{H} 4(\mathrm{CH} 3) 2$ & Sigma-Aldrich, USA & 214,736 \\
\hline Nuclease-free water & $\mathrm{H}_{2} \mathrm{O}$ & Ambion, USA & M9932 \\
\hline Eosin & $\mathrm{C}_{20} \mathrm{H}_{8} \mathrm{Br}_{4} \mathrm{O}_{5}$ & RAL Diagnostics, France & 312,710 \\
\hline RNAsecure reagent & & Thermo Fisher Scientific, USA & AM7005 \\
\hline RNaseZAP & & Sigma-Aldrich, USA & R2020-250 ml \\
\hline Biopsy foam pads & & Simport, Canada & M476-1 \\
\hline Biopsy cassette & & Square Mesh Cassette, Orange & $70,072-0$ \\
\hline Histology cassette & & Thermo Scientific, USA & $12,677,796$ \\
\hline PEN membrane glass slide & & Leica, Germany & $11,505,190$ \\
\hline 0.6-mL microcentrifuge tubes & & Molecular Bioproducts, USA & 3454 \\
\hline ddPCR 96-well PCR plates & & Bio-Rad, USA & $12,001,925$ \\
\hline Pierceable foil heat Seal & & Bio-Rad, USA & $1,814,040$ \\
\hline DG8 cartridges & & Bio-Rad, USA & $1,804,008$ \\
\hline DG8 gasket for ddPCR & & Bio-Rad, USA & $1,863,009$ \\
\hline Droplet generation oil for probes & & Bio-Rad, USA & $1,863,005$ \\
\hline ddPCR droplet reader oil & & Bio-Rad, USA & $1,863,004$ \\
\hline ddRT-PCR kit from Bio-Rad & & Bio-Rad, USA & $186-4021$ \\
\hline
\end{tabular}

while the paraffin was still liquid and transferred to a cold RNase-free surface. The bundles were subsequently transferred vertically and placed upside down in a molding tray (E70182, EMS, USA). The paraffin blocks were maintained at $4{ }^{\circ} \mathrm{C}$ and protected from light.

\section{Microtomy and laser microdissection}

LM collector tubes and the PEN membrane slide were placed under UV light for $30 \mathrm{~min}$. Transversal sections with a thickness of $10 \mu \mathrm{m}$ were cut on an RNase-free microtome (RM2255, Leica, Germany). An eosin-stained root indicates the positions of all the root tips. Both the PEN membrane slide and methanol were prewarmed on a hot plate at $52^{\circ} \mathrm{C}$ for $1 \mathrm{~min}$ while cutting roots. Sections of meristematic and differentiated root tissues were visually identified through analysis of the first $500 \mu \mathrm{m}$ after the first root cap cells. The paraffin sections were then mounted on a PEN membrane glass slide $(11,505$, 190, Leica, Germany) prewarmed at $52^{\circ} \mathrm{C}$ and containing drops of methanol. The sections were air dried until the methanol evaporated, and the slide was dewaxed through two 2.5-min baths in cold xylene. Once the xylene had evaporated, the slide was immediately processed for LM (LMD7000, Leica, USA) using the following laser settings: for 63x magnification, power 22, aperture 1, speed 8, Balance 20, Head Current 80\%,
Pulse Frequency 228, Offset 210; and for 40x magnification, Power 21, Aperture 1, Speed 10, Balance 25, Head Current 100\%, Pulse Frequency 120, Offset 180. The outer cells layer, cortex and stele tissues were collected by gravity in a $0.5-\mathrm{mL}$ tube cap filled with $25 \mu \mathrm{L}$ of extraction buffer from the PicoPure ${ }^{\circ}$ RNA isolation kit (Cat no. KIT0204, ThermoFisher Scientific, USA). The presence of microdissected tissues on tubes was assessed using low magnification (20X). Following the instructions provided with the Arcturus PicoPure kit, the specimens were stored at $-80^{\circ} \mathrm{C}$ until RNA extraction.

\section{RNA extraction and dosage}

RNA extraction was performed in accordance with the instruction manual provided with the PicoPure ${ }^{\circ}$ RNA isolation kit, and this step involved DNase treatment on a column (RNase-Free DNase Set, Cat no. 79254, Qiagen, Germany). The RNA integrity was evaluated using an Agilent 2100 Bioanalyzer system (Cat no. DE72902360, Agilent, USA) with the Agilent RNA 6000 Pico kit (5067-1513, Agilent, USA).

\section{Identification of tissue-specific candidates}

We used the RiceXpro [14, 15] database (http://ricexpro. dna.affrc.go.jp) to identify genes with tissue-specific expression (see Supplemental Figure 3 and Supplemental 
Table 1). We then designed primers and TaqMan probes for one tissue-specific gene and a reference gene that shows constant expression in all root tissues. The primers and TaqMan probes were designed using Primer3 in accordance to the manufacturer's recommendations (Bio-Rad, USA) and were validated by PCR using genomic DNA in a final volume of $25 \mu \mathrm{L}$, which consisted of $2.5 \mu \mathrm{L}$ of $10 \mathrm{x}$ Taq Mix, $1.5 \mu \mathrm{L}$ of $\mathrm{MgCl}_{2}(25$ $\mathrm{mM}), 2 \mu \mathrm{L}$ of dNTP $(10 \mathrm{mM}), 1 \mu \mathrm{L}$ of forward and reverse primers $(10 \mu \mathrm{M})$ and $0.6 \mu \mathrm{L}$ of Diamond Taq (TAQ-I021, Eurogentec, Belgium). The PCR conditions in the thermocycler (Eppendorf ${ }^{\text {sin }} 6,331,000,041$ ) were as follows: $95^{\circ} \mathrm{C}$ for $10 \mathrm{~min}, 40$ cycles of $94{ }^{\circ} \mathrm{C}$ for $30 \mathrm{~s}$, $60^{\circ} \mathrm{C}$ for $60 \mathrm{~s}$, and $72{ }^{\circ} \mathrm{C}$ for $60 \mathrm{~s}$ ), and a final elongation step of $72^{\circ} \mathrm{C}$ for $1 \mathrm{~min}$. The PCR products were analyzed and validated using a $1 \%$ agarose gel (see Table 1 for primers and probes).

\section{RT-ddPCR and RT-qPCR for quantification of gene expression}

RT-ddPCR was performed in a solution containing $2 \mu \mathrm{L}$ of RNA $(0.5 \mathrm{ng} / \mu \mathrm{L})$. A reaction volume of $20 \mu \mathrm{L}$ was used for droplet generation using the RT-ddPCR reaction kit (Bio--Rad, USA), and this volume consisted of $5 \mu \mathrm{L}$ of RTddPCR Supermix, $2 \mu \mathrm{L}$ of reverse transcriptase, $1 \mu \mathrm{L}$ of $300 \mathrm{mM} \mathrm{DTT}, 1 \mu \mathrm{L}$ of the primer/probe pair $(1 \mu \mathrm{L}$ of FAM primer/probe and $1 \mu \mathrm{L}$ of HEX primer/probe for relative expression experiments), $2 \mu \mathrm{L}$ of RNA QSP, and $20 \mu \mathrm{L}$ of RNase-free water. The samples were transferred to eight-channel disposable droplet-generation cartridges, and $70 \mu \mathrm{L}$ of droplet generation oil was added. Each cartridge was then loaded into the QX200 droplet generator (Bio-Rad, USA). After droplet generation, $40 \mu \mathrm{L}$ of the samples was immediately transferred to 96-well PCR plates (ddPCR 96-well PCR plates, Bio-Rad, USA) and sealed with the PX1 plate sealer (Bio-Rad, USA). The RTddPCR conditions on a Mastercycler Nexus Gradient (6, $331,000,017$, Eppendorf, USA) were $60 \mathrm{~min}$ at $50^{\circ} \mathrm{C}, 10$ min at $95^{\circ} \mathrm{C}, 40$ cycles of $30 \mathrm{~s}$ at $95^{\circ} \mathrm{C}$ and $1 \mathrm{~min}$ at $57^{\circ} \mathrm{C}$ and a final denaturation step of $10 \mathrm{~min}$ at $98^{\circ} \mathrm{C}$. The QX200 droplet reader (Bio-Rad, USA) was used to analyze the droplet fluorescence. Each droplet was analyzed individually using a two-color detection system (FAM, HEX). PCR- and PCR-negative droplets were counted to obtain the absolute quantities of the target RNA molecules using QuantaSoft 1.6 Pro (Bio-Rad, USA) software. The results are presented as $1 \mathrm{D}$ plots.

RT-qPCR was performed in a solution containing $2 \mu \mathrm{L}$ of RNA in white Multiwell 96-well plates and sealed with adhesive foil (Roche Molecular Systems Inc., United States). A reaction volume of $10 \mu \mathrm{L}$ was used for qPCR using the iTaq Universal Probes One-Step Kit (Bio-rad, USA Ref 172-5140). This volume consisted of $5 \mu \mathrm{L}$ of iTaq universal probes reaction mix, $0.25 \mu \mathrm{L}$ of iScript advanced reverse transcriptase, $1 \mu \mathrm{L}$ of the primer/probe pair $(1 \mu \mathrm{L}$ of FAM primer/probe and $1 \mu \mathrm{L}$ of HEX primer/ probe for relative expression experiments), $2 \mu \mathrm{L}$ of RNA and $1.75 \mu \mathrm{L}$ of RNase-free water. The RT-qPCR conditions on a Roche LightCycler 480 (Scan Mode Standard) were $10 \mathrm{~min}$ at $50^{\circ} \mathrm{C}, 2 \mathrm{~min}$ at $95^{\circ} \mathrm{C}, 40$ cycles $10 \mathrm{~s}$ at $95^{\circ} \mathrm{C}$ and $1 \mathrm{~min}$ at $60^{\circ} \mathrm{C}$ (annealing, extension and reading).

\section{Supplementary information}

Supplementary information accompanies this paper at https://doi.org/10 1186/s12860-020-00312-y. Additional file 1: Supplemental Figure S1. Preparation of root tip
samples. A) A hydroponic culture system using a floating net. B)
Harvesting of 2-cm-long root tips and staining of a root tip with eosin for
the positioning of root bundles. C) Embedding cassette (right) of root tips
covered with biopsy foam (left). D) Embedding of the whole root bundle
in paraffin.

Additional file 2: Supplemental Figure S2. RIN values obtained after laser microdissection of rice root sections before a) and after optimization steps (b-f). a) The original protocol of [9] b) The RIN value obtained after replacing the initial fixation step with a 5 -min vacuum step, followed by overnight fixation at $4{ }^{\circ} \mathrm{C}$. Cold fixation achieved an RIN value close to three. c) The RIN value after replacing the microwave dehydration steps by additional dehydration steps at a cold temperature $\left(4^{\circ} \mathrm{C}\right)$; the RIN value achieved is approximately 5. d) The RIN value for the complete protocol obtained using a paraffin coating and $3 \times 5$ minutes in the microwave instead of $3 \times 3$ hours. e, f) RIN values obtained for two more repetitions of the complete protocol. The red bar shows an RIN value of 7 as the minimum quality threshold selected for RNA extraction after laser microdissection.

Additional file 3: Supplemental Figure S3. Expression profiling of the putative tissue-specific genes extracted from RiceXpro.

Additional file 4: Supplemental Figure S4. Preparation of RNase-free material prior to sample dehydration and embedding. a) Histological cassettes. b) to d) Elements of the water bath for the microwave: b) lid, c) beaker, and d) fixing system for histology cassettes. e) Glass Petri dish. f) Tongs. g) Stirrers.

Additional file 5: Supplemental Figure S5. qRT-PCR for OsSHR1 A) and EXP'B) using serial dilutions of total root RNA. Diagrams showing the correlations between the $\mathrm{Ct}$ and $\mathrm{pg}$ of RNA per reaction.

Additional file 6: Supplemental File 1. Methods.

Additional file 7: Supplemental Table 1. Genes with tissue-specific expression extracted from RiceXpro.

\section{Abbreviations}

ddPCR: Digital Droplet PCR; LM: Laser Microdissection; ROL: Root Oxygen Loss; FACS: Fluorescence-activated Cell Sorting; INTACT: Isolation of Nuclei Tagged in Specific Cell Types

\section{Acknowledgements}

All LM and histology observations were performed at the Montpellier RIO Imaging facilities at the PHIV site. We thank PHIV platform for their technical support and the French LM Network for their advice. We acknowledge the imaging facility MRI, member of the national infrastructure France-

Biolmaging supported by the French National Research Agency (ANR-10INBS-04, «Investments for the future»). We would also like to thank the two anonymous reviewers for their comments, which significantly improved the quality of our manuscript.

\section{Authors' contributions}

TM, SNS and CB performed laser microdissection experiments, RNA extractions and methodological improvements. SNS and TM designed the primers and probes used in RT-qPCR and RT-ddPCR. The experiments for RT-ddPCR, RT- 
qPCR were performed by LA, FD and SNS. FV and CP drafted the manuscript. All the authors participated in the writing, correction and proofreading of the manuscript. The author(s) read and approved the final manuscript

\section{Funding}

This work was supported by the CGIAR research program on RICE (CRP RICE). Thibault Mounier is partially supported by a Montpellier SupAgro PhD fellowship.

\section{Availability of data and materials}

All the datasets, including videos and photographs, are included in the article and are also available from the corresponding author upon reasonable request.

\section{Ethics approval and consent to participate}

Not applicable.

\section{Consent for publication}

Not applicable.

\section{Competing interests}

The authors declare that they have no competing interests.

\section{Author details}

${ }^{1}$ CIRAD, UMR-AGAP, Université de Montpellier, Avenue Agropolis, F-34398 Montpellier Cedex 5, France. ${ }^{2}$ IAGE Company, Avenue Agropolis, F-34398 Montpellier Cedex 5, France.

Received: 24 September 2019 Accepted: 10 September 2020

Published online: 10 December 2020

\section{References}

1. Takehisa H, Sato Y, Igarashi M, Abiko T, Antonio BA, Kamatsuki K, Minami H, Namiki N, Inukai Y, Nakazono M, et al. Genome-wide transcriptome dissection of the rice root system: implications for developmental and physiological functions. Plant J. 2012;69(1):126-40.

2. Birnbaum K, Shasha DE, Wang JY, Jung JW, Lambert GM, Galbraith DW, Benfey PN. A gene expression map of the Arabidopsis root. Science. 2003; 302(5652):1956-60.

3. Deal RB, Henikoff S. The INTACT method for cell type-specific gene expression and chromatin profiling in Arabidopsis thaliana. Nat Protoc 2011;6(1):56-68.

4. Deal RB, Henikoff S. A simple method for gene expression and chromatin profiling of individual cell types within a tissue. Dev Cell. 2010;18(6):103040.

5. Reynoso MA, Pauluzzi GC, Kajala K, Cabanlit S, Velasco J, Bazin J, Deal R, Sinha NR, Brady SM, Bailey-Serres J. Nuclear Transcriptomes at high resolution using retooled INTACT. Plant Physiol. 2018;176(1):270-81.

6. Evrard A, Bargmann BO, Birnbaum KD, Tester M, Baumann U, Johnson AA. Fluorescence-activated cell sorting for analysis of cell type-specific responses to salinity stress in Arabidopsis and rice. Methods Mol Biol. 2012; 913:265-76.

7. Dinneny JR, Long TA, Wang JY, Jung JW, Mace D, Pointer S, Barron C, Brady SM, Schiefelbein J, Benfey PN. Cell identity mediates the response of Arabidopsis roots to abiotic stress. Science. 2008;320(5878):942-5.

8. Sakai K, Taconnat L, Borrega N, Yansouni J, Brunaud V, Paysant-Le Roux C, Delannoy E, Martin Magniette ML, Lepiniec L, Faure JD, et al. Combining laser-assisted microdissection (LAM) and RNA-seq allows to perform a comprehensive transcriptomic analysis of epidermal cells of Arabidopsis embryo. Plant Methods. 2018;14:10.

9. Takahashi H, Kamakura H, Sato Y, Shiono K, Abiko T, Tsutsumi N, Nagamura Y, Nishizawa NK, Nakazono M. A method for obtaining high quality RNA from paraffin sections of plant tissues by laser microdissection. J Plant Res. 2010;123(6):807-13.

10. Shiono K, Yamauchi T, Yamazaki S, Mohanty B, Malik Al, Nagamura Y, Nishizawa NK, Tsutsumi N, Colmer TD, Nakazono M. Microarray analysis of laser-microdissected tissues indicates the biosynthesis of suberin in the outer part of roots during formation of a barrier to radial oxygen loss in rice (Oryza sativa). J Exp Bot. 2014;65(17):4795-806.

11. Anjam MS, Ludwig $Y$, Hochholdinger F, Miyaura C, Inada M, Siddique $S$, Grundler FM. An improved procedure for isolation of high-quality RNA from nematode-infected Arabidopsis roots through laser capture microdissection. Plant Methods. 2016:12:25

12. Taylor SC, Laperriere G, Germain H. Droplet digital PCR versus qPCR for gene expression analysis with low abundant targets: from variable nonsense to publication quality data. Sci Rep. 2017;7(1):2409.

13. Quan PL, Sauzade M, Brouzes E. dPCR: A Technology Review. Sensors (Basel). 2018;18(4):1271.

14. Sato $Y$, Antonio BA, Namiki N, Takehisa H, Minami H, Kamatsuki K, Sugimoto K, Shimizu Y, Hirochika H, Nagamura Y. RiceXPro: a platform for monitoring gene expression in japonica rice grown under natural field conditions. Nucleic Acids Res. 2011:39(Database issue):D1141-8.

15. Sato $Y$, Takehisa $H$, Kamatsuki K, Minami H, Namiki N, Ikawa H, Ohyanagi $H$, Sugimoto K, Antonio BA, Nagamura Y. RiceXPro version 3.0: expanding the informatics resource for rice transcriptome. Nucleic Acids Res. 2013; 41(Database issue):D1206-13.

16. Henry S, Dievart A, Divol F, Pauluzzi G, Meynard D, Swarup R, Wu S, Gallagher KL, Perin C. SHR overexpression induces the formation of supernumerary cell layers with cortex cell identity in rice. Dev Biol. 2017; 425(1):1-7.

17. Yamauchi T, Tanaka A, Inahashi H, Nishizawa NK, Tsutsumi N, Inukai Y, Nakazono M. Fine control of aerenchyma and lateral root development through AUX/IAA- and ARF-dependent auxin signaling. Proc Natl Acad Sci U S A. 2019;116(41):20770-5.

18. Xu J, Shi S, Wang L, Tang Z, Lv T, Zhu X, Ding X, Wang Y, Zhao FJ, Wu Z. OsHAC4 is critical for arsenate tolerance and regulates arsenic accumulation in rice. New Phytol. 2017:215(3):1090-101.

19. Wang L, Guo M, Li Y, Ruan W, Mo X, Wu Z, Sturrock CJ, Yu H, Lu C, Peng J, et al. LARGE ROOT ANGLE1, encoding OsPIN2, is involved in root system architecture in rice. J Exp Bot. 2018;69(3):385-97.

20. Caldana C, Scheible WR, Mueller-Roeber B, Ruzicic S. A quantitative RT-PCR platform for high-throughput expression profiling of 2500 rice transcription factors. Plant Methods. 2007;3:7.

21. Cui H, Levesque MP, Vernoux T, Jung JW, Paquette AJ, Gallagher KL, Wang JY, Blilou I, Scheres B, Benfey PN. An evolutionarily conserved mechanism delimiting SHR movement defines a single layer of endodermis in plants. Science. 2007;316(5823):421-5.

22. Nakazono M, Qiu F, Borsuk LA, Schnable PS. Laser-capture microdissection, tool for the global analysis of gene expression in specific plant cell types: identification of genes expressed differentially in epidermal cells or vascular tissues of maize. Plant Cell. 2003;15(3):583-96.

23. Kokkat TJ, Patel MS, McGarvey D, LiVolsi VA, Baloch ZW. Archived formalin-fixed paraffin-embedded (FFPE) blocks: a valuable underexploited resource for extraction of DNA, RNA, and protein. Biopreserv Biobank. 2013;11(2):101-6.

24. Athman A, Tanz SK, Conn VM, Jordans C, Mayo GM, Ng WW, Burton RA, Conn SJ, Gilliham M. Protocol: a fast and simple in situ PCR method for localising gene expression in plant tissue. Plant Methods. 2014;10:29.

\section{Publisher's Note}

Springer Nature remains neutral with regard to jurisdictional claims in published maps and institutional affiliations.

Ready to submit your research? Choose BMC and benefit from:

- fast, convenient online submission

- thorough peer review by experienced researchers in your field

- rapid publication on acceptance

- support for research data, including large and complex data types

- gold Open Access which fosters wider collaboration and increased citations

- maximum visibility for your research: over $100 \mathrm{M}$ website views per year

At $\mathrm{BMC}$, research is always in progress.

Learn more biomedcentral.com/submissions 